Contributions to Game Theory and Management, XIII, 173-206

\title{
Review on Supply Chain Network Metrics *
}

\author{
Sajad Kazemi \\ Graduate School of Management, St. Petersburg State University \\ St. Petersburg, 199034, Russia \\ E-mail: s.kazemi_ie@yahoo.com
}

\begin{abstract}
Recent studies focused on the importance of adopting network analysis approaches such as social network analysis in the supply chain networks to better understand and manage the roles of organizations in interorganizational relationships. The main aim of this research is to identify and integrate network analysis metrics in the existent literature in this realm which is applicable to characterize the position and role of organizations in the supply chain network context and their impact on the behavior and outcomes of organizations and the whole supply chain network.

To this aim, we followed a systematic literature review process using Scopus database to identify high-quality papers through several screening stages. Our findings illustrate that there are two main sources of interfirm differences including atomistic properties and relational properties. With an emphasis on relational properties through the lens of network analysis metrics, we integrated influential characteristics on actor's behavior and performance into three main categories of node level, tie level, and network level.

Our findings are applicable to address any emergent phenomenon and the roles of actors based on their position in the network context such as supply chain network and study their behavior and performance.
\end{abstract}

Keywords: Supply chain network, inter-organizational relationships, network analysis, social network analysis, supply chain network metrics.

\section{Introduction}

Early research on supply chain networks (e.g., Esmaeili et al., 2009; Žigić and Maçi, 2011; Hosseini-Motlagh et al., 2019) focused primarily on dyadic interactions between buyers and sellers in which seller represents the terms supplier, vendor, and manufacturer, and buyer represents the distributer, wholesaler, and retailer (Esmaeili and Zeephongsekul, 2010). Also, they mostly have addressed technical issues in engineering and operations management modeling approaches (Min and Zhou, 2002). However, many studies (Borders et al., 2001; Choi and Wu, 2009; Pilbeam et al., 2012) emphasize that dyadic models are inadequate in effectively capture and describe the complex dynamic interactive nature inherent in the supply chain network, and the behavior of actors which are rational locally, will be globally inefficient (Whang, 1995). In this regard, network analysis approach as an emerging interdisciplinary lens is applicable to overcome this theoretical and methodological (Basole et al., 2011).

Network studies and in particular supply chain network studies with different nature of relationships among interacting actors has become increasingly popular over the years (Anderson et al., 1998). They emphasize on the importance of strategic

\footnotetext{
* Research has been conducted with financial support from SPbU grant (project No. 48952577)
} 
alliances, global outsourcing, partnership formation and collaboration, etc. (Akyuz and Erkan, 2010). From a supply chain network perspective, the relative position of actors in relation with other actors influence their both strategy, behavior, and outcomes (Borgatti and Li, 2009; Bellamy et al., 2014; Kim et al., 2011). In this complex network of relationships that the actors are embedded in, economic and social dimensions are critical to consider (Choi and Kim, 2008) and hence, it is imperative to study the role and importance of actors derived from their embedded positions in the inter-organizational relationships (Borgatti and $\mathrm{Li}, 2009$; Kim et al., 2011). In this regard, several studies (e.g., Borgatti and Li, 2009) proposed to analyze the structural characteristics of supply chain networks using the social network analysis as a formal and quantitative modeling approach (Kim et al., 2011).

In the supply chain network context total domination of one actor is not possible over resources and activities of other actors (Heikkinen et al., 2007; Knight and Harland, 2005). If supply network members understand their role, it is more likely to coordinate and harmonize their actions with each other with the objective of providing value for the entire network which result in greater value across actors (Yim et al., 2013). It then becomes important to study different leader and follower roles, status roles, operational roles (e.g., customer, supplier, producer, etc.), and so on as the roles of formal organizations (Zaidat et al., 2005). Consequently, there is a window of opportunity to review and illustrate the significance and application of adopting network analysis approaches in the supply chain networks to better understand and manage actors' roles. For example, Burkhardt and Brass (1990) and Ibarra (1993) illustrated that the position of actors in the network affects their power and influence. Others have linked network position to such issues as innovation adoption (e.g., Ibarra, 1993), brokering (e.g., Pollock et al., 2004; Zaheer and Bell, 2005), higher innovation (e.g., Bellamy et al., 2014), higher performance (e.g., Sanou et al., 2016), etc.

Therefore, the fundamental objectives of this systematic literature review are to identify and classify network analysis studies in the supply chain network context, organize them into an integrative framework, and suggest future research directions.

The remainder of the paper is structured as follows. Section 2 describes network analysis in the literature. Sections 3 presents supply chain networks, interorganizational relationships, and potential advantages. Section 4 provides the main body of literature review on supply chain network analysis metrics and the details of our integrative framework. In Section 5, we present the importance of roles and positions in the supply chain network context and the application of the concept of centrality. Section 6 provides conclusion and some direction for future interdisciplinary research opportunities.

\section{Network Analysis in the Literature}

\subsection{Network}

A network is a generalization of graph, comprising a set of vertices (actors) and a binary interaction (tie or link) which connect these actors (Rapoport, 1979). The repeated interactions among actors will form a pattern of direct and indirect ties which is defined as network structure (Hoang and Antoncic, 2003; Knoben et al., 2006). There is a broad literature on network studies which have been published across a wide variety of fields and in particular among organizational and economic scholars (Knoben et al., 2006). In this regard, theoretical contributions formed a 
body of knowledge known as network theory, and is defined as the mechanisms and processes, through them a set of actors which potentially are related together and form the network structure yield certain outcomes for each actor and the whole network (Omta et al., 2002; Borgatti and Halgin, 2011). These theoretical and empirical studies focus on three elements of network including (1) the nature of the content that is exchanged between actors; (2) governance mechanisms; and (3) the network structure.

Network content provides its members access to resources and capital through network ties (Gulati et al., 2000). Actors in the network can benefit many opportunities for sharing various kinds of resources such as financial (Keister, 1998), institutional (Baum and Oliver, 1991), knowledge and information resources (Uzzi, 1996; Dyer and Singh, 1998; Dyer and Nobeoka, 2000) etc. Network provides the actors the possibility of different types of interactions (client referrals, shared resources, shared information, etc.) which can be evaluated from the extent or strength of each relationship viewpoint (whether it occurs through referrals only, through referrals and resources, through several types of interactions, etc. within the same link), or what is termed multiplexity in network terminology.

Network governance. Any economic exchange among actors needs an agreement upon the way of dividing costs, benefits, and risks (Williamson, 1985) which is called the governance mechanism (Williamson, 1996). There are three governance mechanisms including (Powell et al., 1990; Meijer, 2009, p.69):

1) A market governance mechanism where buyers and sellers continually seek the best choice in their single-term transactions and move to another trade partner if it is more beneficial for them. In such a governance mechanism, all actors have full and symmetric information which is known as perfect market, and the optimal price will be determined by supply and demand curve in a cost and benefit analysis. In other words, there is no associated costs of business that do not add value to the product. These costs are defined as ex ante cost of contract or ex post cost of opportunism, including costs of searching, bargaining, monitoring and enforcing which is called transaction costs (Williamson, 1985; Coase, 1937).

2) A hierarchy governance mechanism provides the actors with purchasing production capacity of the other actors through a contract. In other words, the buyer employs the seller through this mechanism.

3) A network governance mechanism includes a select, persistent, and structured set of autonomous actors engaged in network activities based on implicit and openended contracts which are supported by social mechanisms like influence (Thorelli, 1986; Krackhardt, 1990) to adapt to contingent environment and to coordinate and secure exchanges (Jones et al., 1997). It provides independent actors with the possibility of controlling network processes through long-term relationships. The interconnection of links through shared end points forms paths that indirectly connects all actors together which are not directly tied. This path yields a particular network structure, and each actor occupies a position within this structure. Each network has a boundary which is defined by choosing a set of actors and the type of links, and this is determined by a researcher (Borgatti and Halgin, 2011). This governance mechanism undergirds and coordinates network exchanges. One of the critical factors which can enhance the quality of the resource exchanges in the network is trust among actors (Larson, 1992; Lorenzoni and Lipparini, 1999). Trust reduces transaction costs for example monitoring and bargaining costs in reaction 
to environmental changes (Williamson, 1993; Wu et al., 2009). However, threat of ostracism and loss of reputation (Portes and Sensenbrenner, 1993; Jones et al., 1997) are also supportive criteria for this network exchanges rather than legal enforcement.

Therefore, scholars recognize networks as a form of governance with its structure and operating logic (Miles and Snow, 1992) which emphasize on sociality of exchanges among actors and the transactions which are based on relationships, mutual interests, and reputation (Moretti, 2017, p.11). These social mechanisms in network governance reduce transaction costs which provides it with comparative advantage over markets and hierarchies (Jones et al., 1997).

Williamson (1996) assumes that organizations use a mix of governance mechanisms with the lowest transaction costs which leads to better performance of the whole network. According to this view, hierarchical governance structures should be favored when opportunism is likely and transaction costs are high. Market exchange should be preferred when contracts are readily written and enforced and transaction costs are low. If we extend this for alliances, then alliances make sense in more intermediate situations when transaction costs are not so severe as to require hierarchical control but are not so low as to enable market-based exchange. When networks perform better, they are capable to provide higher value for the end customer and higher profit for the actors in the network. For example, 1) actors in the network ideally minimize searching cost for a partner as they know well each other. However, the situation should not be in a way to create the lock-in problem, where actors are dependent on their partners, and they are unable to contact a new partner without substantial switching cost for the products and services. Accordingly, lock-in problem may result in either barriers for new market entrants with high costs or antitrust action with lower costs against a monopoly condition where there is only one supplier of a particular product or service. 2) The frequency of bargaining for those partners which have long-term interaction and agreements will be ideally minimized. 3) Monitoring costs in those long-term agreements will be ideally minimized, where partners can trust mutually and have better knowledge about each other's business situation. 4) Enforcement costs will be ideally minimized as partners in the network trust each other and they are aware of their consequent individual performance on the whole network. However, in many networks the situation will not be ideally like these, and they cannot trust each other where they think the other partner is taking their advantages (Meijer, 2009, p.18).

Network structure. It is typically asserted by organizational sociologists that network formation is driven by exogenous factors like resources or the social structure of resource dependence (Pfeffer and Salancik 1978; Burt 1983). Following this view, creating ties among actors is based on satisfying the needs (actor creates tie with another actor who us owner of resources or controls them) and managing uncertainties and constraints (Gulati and Gargiulo, 1999). Network structure illustrates the position of actors and the pattern of ties among them. From the one hand, the main idea is that this patter is unique, provides the opportunity for sharing resources, affect the behavior and performance of actors, and potentially confers competitive advantage (Gulati et al., 2000; Zaheer et al., 2010). For example, Zaheer and Zaheer (1997) and McEvily and Zaheer (1999) illustrate in their studies that how network structure and its characteristics affect the performance and competitive capabilities. Similarly, Podolny (1993) demonstrate how ties affect returns characteristics in banking industry and Baker and Faulkner (1991) 
who emphasize on the influence of ties' pattern on performance and entrance of organizations in the movie industry. However, there are also some studies who have contrary opinion about the positive influence of structure on performance. On the other hand, network may limit its members from accessing opportunities and information outside the network which is known as lock-in effect (Ingram and Baum, 1997) or puts a constraint on non-participant actors which may benefit members for example by providing them knowledge for R\&D activities (Westney, 1993). Lock-in and lock-out effects occur because in many situations, ties formed with one actor place constraints on ties with others (Gulati et al., 2000). Consequently, network structure and ties may negatively influence firm performance (Gulati et al., 2002).

Therefore, the position of actors within the network structure affect their performance considering their differences in accessing resource flows. In this regard, a variety of approaches and measures drawn from network theory have been developed to analyze networks, positions in the networks, network structure, social interaction among actors within the network structure, and all related problems. To study these areas and to understand actions of actors in the context of structured relationships, network analysis is required to operationalizes structures in terms of networks of linkages among units.

\subsection{Network Analysis}

Network analysis is a set of integrated techniques draws on theories from the social, organizational, and complexity sciences and leverages graph theoretic methods and network theory to characterize, model, analyze, and visualize relations, structures, dynamics, and strategies which is emerged from repeated interactions among actors in the network (Bellamy and Basole, 2013; Chiesi, 2001). As a basic assumption, this analysis allows better explanations of social phenomena. Implementing mathematical language of graph theory and matrices as well as relational algebra enable it to operationalize actors and their relations within the concept of the social network and study the influence of social structure of relationships among network actors (e.g., individuals, groups, and organizations) on their behavior and outcomes (Chiesi, 2001).

The methods of network analysis grounded in important social phenomena and provided clear formal statements and measures of social structural properties which created the term "social network analysis" in the literature (Wasserman and Faust, 1994). Network perspectives are based on the belief that the position of actors within the social network and the social context in which actors are embedded affect the economic actions of actors (Gulati, 1998). In short, the social network analysis provides an appropriate approach to investigate the network structure and the position of actors.

\subsection{Social Network Analysis}

Social network analysis in general concerns the behavior of actors (e.g., individuals, groups, organizations, etc.), the social pattern of relationships among them as network structure (e.g., material transactions, flow of resources or services, behavioral interactions, etc.) and corresponding features, and the interactions between the two within a network (Chang et al., 2012, Moliterno and Mahony, 2011). The concept of a "network" emphasizes that each actor has ties to a set of actors, and the phrase of "social network" refers to the set of actors and their ties (Wasserman and Faust, 1994). It relies on structural explanations of network outcomes and 
provides a set of analytical tool framework for testing theories concerning structure of relationships among actors. For this, it considers ties and actors as units of analysis which represent the network, and focuses on analyzing configuration of ties (Wasserman and Faust, 1994; Moretti, 2017).

Social network analysis involves theories, models, and applications that are represented in terms of relational concepts or processes which indicates that tie is the basic component of network theories. Clearly, it is necessary to consider specific sorts of ties for each type of actors which is relevant or measurable. So, the relation of actors in a dyadic level is a property of the dyad and not inherently a characteristic of individual actor (Wasserman and Faust, 1994). There are a lot of efforts to legitimize it as a theory by collecting and summarizing its main concepts, theories, and limitations (e.g., Borgatti et al., 2009; Kilduff and Brass, 2010). For example, this approach provides an appropriate theoretical framework in investigation the features of network structure and their impact on organizational performance (Powell et al., 1999), firm innovation (Bellamy et al., 2014), individuals' opportunities (Uzzi, 1997), etc.

There are several key concepts and terms at the heart of network analysis which are fundamental in discussing social networks. Therefore, before further explanations of our research area we need to understand the corresponding terminology in social network analysis.

Terminology of social network analysis. Studies on social network analysis area have been directed by a shared glossary of the main terms and concepts used in the theories corresponding the actors, ties, and structure of network. Here, we present a definition for a set of terms and concepts which is used in this doctoral research (Table 1).

Table 1. Terminology of social network analysis

\begin{tabular}{|c|c|}
\hline Term/ Concept & Description \\
\hline Actor & $\begin{array}{l}\text { Actors are discrete individual, collective social entity, organi- } \\
\text { zation, or nation-states in the world system. It is also known } \\
\text { as "node" in the network terminology (Wasserman and Faust, } \\
\text { 1994; Kilduff and Tsai, 2003; Moretti; 2017; Swierczek, 2018). }\end{array}$ \\
\hline Ego & The focal actor (Wasserman and Faust, 1994). \\
\hline Alter & $\begin{array}{l}\text { The other actors which are connected to focal actor (Wasser- } \\
\text { man and Faust, 1994) }\end{array}$ \\
\hline Position & $\begin{array}{l}\text { It to a set of actors which are embedded in the network } \\
\text { structure with corresponding relations through network ties } \\
\text { (Wasserman and Faust, 1994; Kinnie et al., 2005). }\end{array}$ \\
\hline Role & $\begin{array}{l}\text { It refers to expected behaviors through patterns of relations } \\
\text { toward other actors or positions (Wasserman and Faust, 1994; } \\
\text { Kinnie et al., 2005). }\end{array}$ \\
\hline Status & $\begin{array}{l}\text { A series of observable characteristics associated with a partic- } \\
\text { ular role (Kinnie et al., 2005). }\end{array}$ \\
\hline
\end{tabular}




\begin{tabular}{|c|c|}
\hline Relational tie & $\begin{array}{l}\text { Any type of linkages that connect actors to one another by } \\
\text { social ties which can be behavioral interactions, associa- } \\
\text { tion or affiliation, business transactions, etc. (Wasserman } \\
\text { and Faust, 1994; Kilduff and Tsai, 2003). }\end{array}$ \\
\hline Asymmetric tie & $\begin{array}{l}\text { A one-way tie or link between actors (Wasserman and } \\
\text { Faust, 1994). }\end{array}$ \\
\hline Dyad & $\begin{array}{l}\text { The basic level of linkage or relationship between two ac- } \\
\text { tors. The tie is a property of pairs and is not pertain to } \\
\text { individual actor (Wasserman and Faust, 1994; Kilduff and } \\
\text { Tsai, 2003). }\end{array}$ \\
\hline Triad & $\begin{array}{l}\text { The level of linkages or relationships among a subset of } \\
\text { three actors with (possible) tie(s) among them (Wasser- } \\
\text { man and Faust, 1994; Kilduff and Tsai, 2003). }\end{array}$ \\
\hline Subgroup & $\begin{array}{l}\text { Any subset of actors with all (possible) tie(s) among them } \\
\text { (Wasserman and Faust, 1994; Kilduff and Tsai, 2003). }\end{array}$ \\
\hline Clique & $\begin{array}{l}\text { A subgroup of actors in which all actors have direct ties } \\
\text { with each other (fully interconnected actors) (Wasserman } \\
\text { and Faust, 1994; Kilduff and Tsai, 2003). }\end{array}$ \\
\hline Density & $\begin{array}{l}\text { The degree of interconnectedness of actors or the overall } \\
\text { connectedness of a network. In other word, it is the num- } \\
\text { ber of total ties in a network relative to the number of } \\
\text { potential ties (Wasserman and Faust, 1994; Kilduff and } \\
\text { Tsai, 2003; Moretti; 2017; Swierczek, 2018). }\end{array}$ \\
\hline Network plot & $\begin{array}{l}\text { A visual representation of all actors in the network and } \\
\text { the links (Wasserman and Faust, 1994). }\end{array}$ \\
\hline Network size & $\begin{array}{l}\text { The number of actors in a network (Wasserman and Faust, } \\
\text { 1994; Kilduff and Tsai, 2003; Moretti; 2017). }\end{array}$ \\
\hline Network intensity & $\begin{array}{l}\text { The sum of the average infrequency of interaction score } \\
\text { for each actor (Wasserman and Faust, 1994; Kilduff and } \\
\text { Tsai, 2003; Swierczek, 2018). }\end{array}$ \\
\hline Multiplexity & $\begin{array}{l}\text { The number of different types of relation (more than } \\
\text { one) in the same link between two actors that affect the } \\
\text { strength of the relationship (Wasserman and Faust, 1994; } \\
\text { Kilduff and Tsai, 2003; Moretti; 2017). }\end{array}$ \\
\hline Network typology & $\begin{array}{l}\text { Classification of networks according to their structural } \\
\text { and functional features (Wasserman and Faust, 1994; } \\
\text { Moretti; 2017). }\end{array}$ \\
\hline Network topology & $\begin{array}{l}\text { Arrangement and configuration of actors and their ties in } \\
\text { a network (Wasserman and Faust, 1994; Moretti; 2017). }\end{array}$ \\
\hline Network centralization & $\begin{array}{l}\text { It captures the extent to which the overall connectedness is } \\
\text { organized around particular actors in a network (Wasser- } \\
\text { man and Faust, 1994; Kilduff and Tsai, 2003; Moretti; } \\
2017 \text { ). }\end{array}$ \\
\hline Network complexity & $\begin{array}{l}\text { It refers to the number of dependency relations within a } \\
\text { network (Wasserman and Faust, 1994; Kilduff and Tsai, } \\
\text { 2003; Moretti; 2017). }\end{array}$ \\
\hline
\end{tabular}




\begin{tabular}{cl}
\hline Structural hole & A structural hole refers to an "empty space" between two \\
& actors that can be spanned by a third actor who can be- \\
& come the only intermediary between them (Wasserman \\
& and Faust, 1994; Kilduff and Tsai, 2003; Moretti; 2017). \\
\hline Network cohesion The two actors are ties by a strong network connection \\
either directly or indirectly through mutual third-party \\
ties (Wasserman and Faust, 1994; Kilduff and Tsai, 2003; \\
Moretti; 2017). \\
\hline Centrality & It refers to the extent to which an actor occupies a posi- \\
& tion in the network which is relatively known as the most \\
& important, prominent, and strategic position. The impor- \\
& tance, prominence, and strategic terms are perceived dif- \\
& ferently in the literature which led to various measures of \\
& centrality (Borgatti and Everett, 2006; Kiss and Bichler, \\
& 2008; Vurro et al., 2009; Zaheer et al., 2010; Kim et al., \\
& 2011; Sanou et al., 2016). \\
\hline Ability of an actor to use their resources, capabilities, and \\
competencies (Barney, 1991; Teece et al., 1997; Prahalad \\
and Hamel, 1990; Smith, 2008), and embed them within \\
the influence, control, and motivation strategies which \\
they use to achieve and maintain significant market pen- \\
etration and communicate their desires to each other in \\
the network (Dahl, 1957, p.202; Emerson, 1962; El-Ansary \\
and Stem, 1972; Etgar, 1976). \\
\hline A tie that links an actor with another actor that is not \\
connected with its partners. In other words, a tie property \\
that measures the extent to which a tie forms a bridge to \\
span the structural hole (Cornwell, 2009; Gulati et al., \\
2002). \\
\hline An actor property which refers to the control over bridging \\
(Everetta and Valente, 2016). \\
\hline A tie that links an actor with another actor which is also \\
connected with at least one of its partners (Tortoriello et \\
al., 2012; Gulati et al., 2002). \\
It refers to the opposite of structural holes, and is often \\
measured as ego-network density. A network with com- \\
plete closure is one in which all actors are tied to each \\
other, and in such cases, density reaches its theoretical \\
maximum of one (Coleman, 1990, p. 310; Zaheer et al., \\
2010). \\
\hline Bridging
\end{tabular}

\subsection{Core Ideas in the Network Theory}

Following the study of Wasserman and Faust (1994) as one of the basic sources for many researchers who investigate research questions in the context of network using network theory framework, we need to attention that the attributes of actors (e.g., size, age, productivity, etc.) in the network are secondary and relational ties are primary. In other words, attributes of actors are understood in terms of network structure and corresponding patterns of ties among actors. Hence, researchers can also directly study these patterns without referring to attributes of actors in im- 
plementing a network viewpoint. Accordingly, there are four core ideas that drives studies, incorporating network perspective. These core ideas are not completely distinct concepts but profoundly interrelated (Wasserman and Faust, 1994; Balkundi and Kilduff, 2006; Kilduff and Brass, 2010; Moretti, 2017):

Relations among actors. The most important distinguishing feature of network research is emphasizing on relations among actors rather than an exclusively focus on the attributes of actors. It is based on the fact that the behavior of agents is influenced not only by their individual attributes but also by their relations in the network. For example, Kraatz (1998) investigated the relations among private colleges in the United States.

Embeddedness. This idea emphasizes that economic transactions take place within a network of social relationships. Embeddedness means that actors tend to transact with network members (Granovetter, 1985). In other words, it highlights the preference for interacting with those actors within the community rather than those outside the community. It provides an interpretation concerning the governance of economic actions in terms of trust and cohesion, and can be seen as an organizing logic different than hierarchy and market relations (Powell, 1990).

Social patterning means the existence of a social structure characterized at the same time by the presence and absence of ties between agents, the understanding of which can help to explain economic outcomes. By addressing patterns of network structure, it is possible to study simultaneously actor, group, and network characteristics.

Utility of network connections. It is based on the fact that social network connections represent constraints and opportunities for actors, and thus the network of relationships matters in reaching particular outcomes.

\section{Supply Chain Network}

Chopra and Meindl (2016, p.1) in their book entitled "Supply Chain Management: Strategy, Planning, and Operation" indicate that a supply chain is defined as all involved parties in fulfilling a customer request, directly or indirectly. It is typically comprising a variety of stages, including customers, retailers, wholesalers/distributors, manufacturers, and component/raw material suppliers with corresponding actors in each stage. Each stage in a supply chain is connected through the flow of products, information, and funds. These flows often occur in both directions and may be managed by one of the stages or an intermediary (Figure 1).

The emergence of supply chain in the 1980s was with expanding production and distribution optimization across the borders of the firm (Simchi-Levi et al., 2000). In other words, improvements moved from inside the company to the whole supply chain from raw materials to the final customer. Following such a movement, Lazzarini et al. (2001) described two perspectives of supply chain and network to analyze supply across the borders of a firm. In the supply chain perspective, a set of sequential transactions are organized vertically to create value in several successive stages. These vertical interdependencies consist of a forward flow of products, a backward flow of money, and a backward and forward flow of information between organizations engaged in sequential stages of production (Christopher, 1998; 


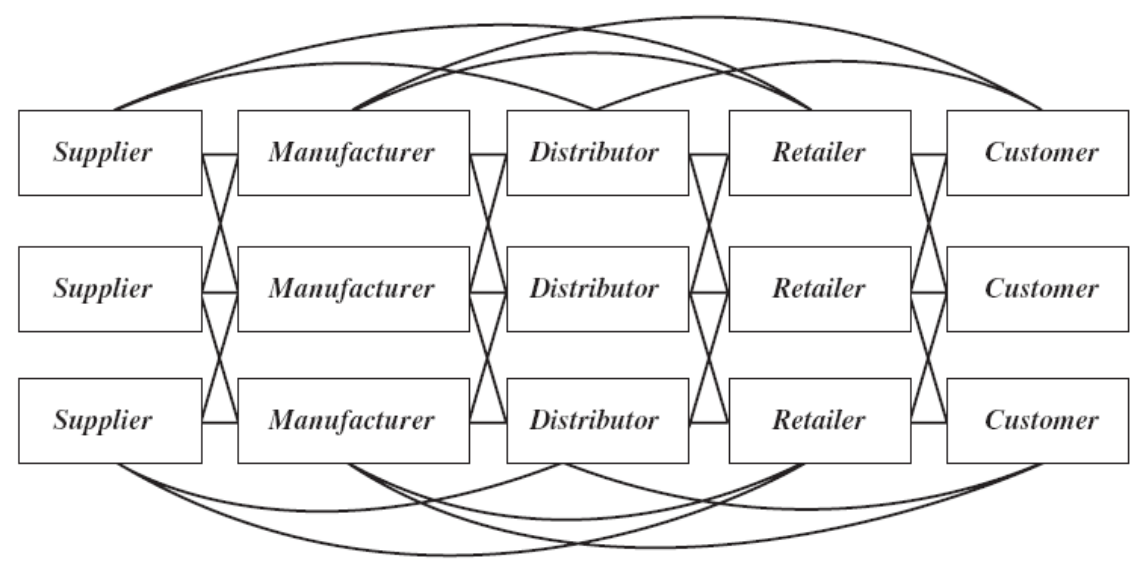

Fig. 1. Supply chain stages (Chopra and Meindl, 2016, p.3)

Simchi-Levi et al., 2000). However, in the network perspective, the focus is on the horizontal and vertical structure of inter-organizational relationships or "ties" that while it can be confining, at the same time it is shaped by the actions of actors (Granovetter, 1973; Burt, 1992). So, whereas supply chain more concentrates on vertical flows and transactions, the network perspective adds a focus on cooperative efforts and transactions between actors in horizontal level (Meijer, 2009). In this regard, Christopher (1992) point out that whilst supply chain is a demand driven chain by the market and not by suppliers, the word "chain" should be replaced by "network" since several actors in each level of supply chain are included.

Therefore, following Christopher (1992) and Nagurney and Li (2016), supply chain network will be defined as a network of connected and interdependent organizations, working through upstream and downstream communications in the different processes and economic activities. They participate in the processes of the production, delivery, and sales of values in the form of products and services for ultimate consumer, and control, manage, and improve the flow of materials, money, and information between stages.

The contracts among actors in a supply chain network involve a set of transactions and corresponding costs, including searching, bargaining, monitoring and enforcing costs (Williamson, 1985; Coase, 1937). These four sources of transaction costs can be discussed from different governance mechanisms' perspectives (Table 2) which affect the transaction among actors, and companies usually prefer a mix of these mechanisms to minimize these costs (Williamson, 1996).

\subsection{Nature of Relations in Inter-Organizational Networks}

Any analysis of inter-organizational networks puts emphasis on three aspects of actors (organizations), ties and relations (the links that facilitate transitivity, reciprocity, directionality, and multiplexity of content), and the overall network configuration, or network structure. The inter-organizational relationships have been studied in several studies through different viewpoints and categories. In this research we consider a spectrum of relational forms (Figure 2.2) in which competition and collaboration are in two opposite ends, depending on degree interdependency among actors in achieving outcomes and the goal of relationships (Gulati et al., 
Table 2. Transaction costs in three governance mechanisms (Meijer, 2009)

\begin{tabular}{|c|c|c|}
\hline & Bargaining & Monitoring \\
\hline Market & $\begin{array}{l}\text { Price information } \\
\text { can be reached } \\
\text { through some } \\
\text { intermediaries like can be on prod- } \\
\text { clearing hot's characteris- } \\
\text { and from public tics and price. } \\
\text { information or } \\
\text { auction. }\end{array}$ & $\begin{array}{l}\text { In each trans- } \\
\text { action through Through legal insti- } \\
\text { checking the tutions. The trans- } \\
\text { quantity and action will not hap- } \\
\text { quality infor- pen in case of non- } \\
\text { mation. }\end{array}$ \\
\hline Network & $\begin{array}{l}\text { Information can } \\
\text { be transferred It is on all as- } \\
\text { among companies pects of the cur- } \\
\text { with close link or rent and future } \\
\text { indirectly between transactions. } \\
\text { business partners. }\end{array}$ & $\begin{array}{l}\text { There are several } \\
\text { All necessary mechanisms which } \\
\text { Information enforce actors ad- } \\
\text { is available here to agreements } \\
\text { through a such as network } \\
\text { shared process pressure, reputa- } \\
\text { between actors. tion, and long-term } \\
\text { interactions. }\end{array}$ \\
\hline Hierarchy & 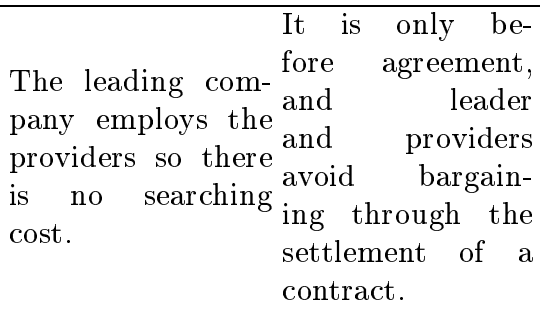 & $\begin{array}{l}\text { The enforcement } \\
\text { Of quality, power of leader } \\
\text { quantity and through its author- } \\
\text { process by ity to break the } \\
\text { the leading contract and to im- } \\
\text { company. nose fines in case of } \\
\text { nonconformances. }\end{array}$ \\
\hline
\end{tabular}

2000; Rudzki and Trent, 2010, p.121). Despite scholars in this realm have an intuitive notion of what collaboration is, this concept usually is confused with the concept of cooperation as there are a lot of different applications of them and related concepts such as communication and coordination (Camiranha-Matos and Afsarmanesh, 2008). While collaboration and cooperation are both considered as win-win relational strategies, they are distinguishable in their nature. To better understanding, we provide a definition and related explanations for them:

Competition or adversarial relationship is an actors' orientation to achieve a position with higher performance and to gain a competitive advantage over other actors through either manipulating the structural parameters of an industry to its advantage or developing inimitable distinctive competencies (Lado et al., 1997). It can be considered as a zero-sum game orientation in which actors compete to acquire resources for effective market position with superior financial performance, and as consequence one actor wins and other actors lose. In other words, holding a competitive advantage over competitors means to be more profitable than competitors over the long term and economic rents accrue to actors that can acquire and utilize scarce resources more efficiently than other firms (Snow, 2017; Lado et al., 1997).

Cooperation relationship is a process to share complementary competencies, capabilities, and resources, or leveraging them for achieving compatible goals of actors which is not possible to be accomplished alone (Gnyawali et al., 2006). In other words, it is achieved by division of labor among participants through reciprocities, 
formal or informal arrangements to share information and exchange resources (not necessarily symmetrical), support managerial and technical training, supply capital, and/or provide market information (Polenske, 2004; Thomson and Perry, 2006; Camiranha-Matos and Afsarmanesh, 2008). There is a transition from cooperation to collaboration when actors pursue a mutual goal (Thomson and Perry, 2006).

Coordination. There are too many different definitions with little agreements in this regard. Accordingly, drives from several studies (Cheng, 1983; Malone and Crowston, 1994; Alexander, 1995:14; Camiranha-Matos and Afsarmanesh, 2008), we can define coordination relationship as an actors' orientation to achieve more efficient results by recognizing and managing the interdependencies between actors and joint efforts harmoniously toward a set goal through systematic framework of rules in which mutual adjustment and aligned activities of actors are logically consistent and coherent. It can be viewed as jointly decision making, mutual adjustment between relational and self-interested actors so that uncertainties can be reduced and transaction cost will be minimized.

Collaboration has a lot of different definitions such as coordination with some commonalities and differences (Tomson and Perry, 2006). Hence, driving from these studies (e.g., Wood and Gray, 1991; Camiranha-Matos and Afsarmanesh, 2008) with focus on Tomson and Perry (2006) we define collaboration as a process that actors which need for resources and risk sharing due to resource scarcity are engaged in a high degree and long-lasted exchange derived from high degree of interdependence, and aggregating individual preferences into collective decisions derived from negotiation among competing interests, expectations, and self-interested motivations. Therefore, autonomous actors in order to share risks, resources, responsibilities, and rewards interact through formal and informal negotiations to create joint rules and structures which govern their relationships toward collective decisions for the mutually beneficial interactions. This definition involves reasoning of a high level of aggregated actions comparing with cooperation or coordination, also cooperation and collaboration are at the two ends of spectrum in terms of interaction, integration, commitment, and complexity (Tomson and Perry, 2006) (Figure 2). Also, in comparing competition with collaboration, there is a clear and sharp boundary among organizations in pure competition rather than collaboration which is rooted in tendency of actors to taking full control over activities through the internal exploitation of competencies, capabilities, and resources and to be the first and sole beneficiary actor by capturing higher market segment (Oliver, 2004).

Interdependence, interaction, integration, commitment, and complexity among actors

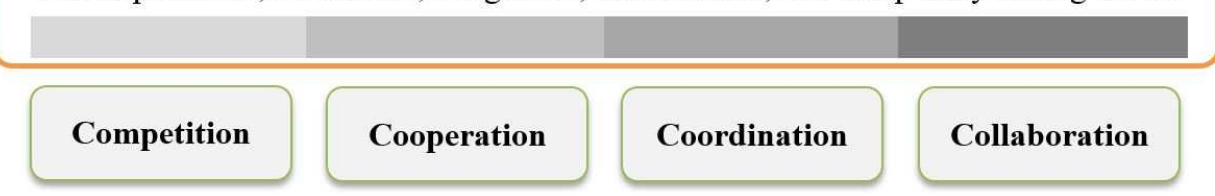

Fig. 2. Continuum of inter-organizational relationships

One of the main theoretical foundations in the domain of supply chain and network where the organization is the unit of analysis is found mostly in the network 
theory. This approach focuses on the dynamics of the relationship between a set of social-economic actors in a social-business network environment, and the basic assumption of this network is that one actor is dependent on the other actor in terms of under-control resources (Powell, 1990).

In the supply chains, the processes and the interaction of parties all together affect the behavior, function, characteristics, and performance of actors and the supply chain as a whole (Cloutier et al., 2010). In this regard, a comprehensive understanding of the behavior and performance of actors and supply chains requires a well study of social and technical issues (Bellamy and Basole, 2013). Since the structures among actors may be behavioral, social, political, or economic, social network analysis thus is applicable to allow a flexible set of concepts and methods with a wide range of interdisciplinary appeal (Wasserman and Faust, 1994).

Social network analysis can be used to study network theoretic constructs with equal efficacy at various levels of analysis (Moliterno and Mahony, 2011) such as individual level (Obstfeld, 2000) and interfirm collaboration network level (Ahuja, 2000). Methodological advantages of social network analysis in the fields of logistics and supply chain management within supply chain and supply network contexts has been acknowledged by several researchers (Choi et al., 2001; Ellram et al., 2006; Carter et al., 2007; Ketchen and Hult, 2007; Kim et al., 2011). For example, social network analysis approach has been considered as an instrument in exploring behavioral mechanisms of supply networks (Borgatti and $\mathrm{Li}, 2009$ ) and understanding the operations of supply networks (Kim et al., 2011) both at the whole network and individual firm levels. It also is important in study of critical positions within the supply network and the influence of supply network structure on the behavior and performance individual actors and the whole network.

To this aim, we need to implement the social network analysis as an interdisciplinary approach for investigating social, organizational, and complexity structures among a set of actor and ties that connect them. It provides the possibility of visualizing the structure, dynamics, and strategies and analyzing the relations among actors, their behaviors, and outcomes (Wasserman and Faust, 1994; Chiesi, 2001; Bellamy and Basole, 2013). In this regard, social network scholars (e.g., Everett and Borgatti, 1999; Freeman, 1977, 1979; Krackhardt, 1990; Marsden, 2002) have developed a range of network metrics to characterize the dynamics inside a social network such as supply chain network which are necessary to investigate the social roles, positions, relations, and their impact on individual outcomes and the network as a whole. Therefore, a well understanding the literature of network analysis and social network analysis in the supply chain and supply chain network contexts is required for two purposes 1) study of behavior and performance of actors and the supply chain network as a whole 2) study of any emerging phenomenon in these contexts in relation with the behavior and performance variables.

\subsection{Potential Advantages and Outcomes of Inter-Organizational Networks}

An extensive body of network studies have focused on highlighting the benefits that actors drive from network (Moretti, 2017; Gulati et al., 2011). In fact, different properties related to various elements of network including network position, ties, and structure are able to provide network members and the whole network some advantages (Moretti, 2017; Gulati et al., 2011). According to the social capital theory, networks provide resource accessibility for network positions embedded in the 
network structure (Gulati et al. 2011). There are several theoretical contributions based on the network analysis which study resources and information which actors may benefit in their networks such as the strength of the ties (Granovetter, 1983) and structural hole (Burt, 1992). This resource accessibility provided by network relationships has been studied by several scholars and interpreted into various advantages and outcomes. Investigating and collecting a complete list of these advantages and outcomes are beyond the scope of this research, hence for the main aim of this section we just focus on the most cited advantages and outcomes related to the scope of this doctoral research in the supply chain network context.

Performance To generate higher performance, organizations must establish an environment in which they have access to shared resource pool, share losses and risks with other actors, and decide jointly with other partners in the network (Um and Kim, 2019). One of the underlying theoretical foundation that can be used to explain the connection of organizational performance and network is the transaction cost economics (Williamson, 1985), focusing on the financial benefits and cost reduction opportunities driving from collaborative relationships, actors' accessibility to resource and capabilities beyond their organizational boundaries in inter-organizational networks (Cao and Zhang, 2011). Higher efficiencies in sourcing, planning, producing, and distributing align with sharing losses and gains will enable actors to show better performance in collaborative networks (Um and Kim, 2019). In this regard, the Relational view (RV) theory also suggests that actors generate higher performance in networks through an exchange relationship which cannot be made in isolation (Dyer and Singh, 1998).

Network activities of organizations such as information gathering, supplier selection, bargaining, and coordinating with suppliers require a cost that can be avoided in case of embeddedness of organizations in the inter-organizational relationships characterized by trust, repeated exchange, consolidated coordination mechanisms, and so forth (Moretti, 2017). For example, Uzzi (1997) found that long-term, relational embeddedness are conducive to superior-quality production compared with arm's-length relationships. He believes the reason for this result lies in better communication about issues pertaining to quality that the two partners developed thanks to their well-established relationship in a network.

Efficiency. Networks enable members to access timely a large number of different actors which are sources of resources, information, and knowledge through small number of ties (Burt, 1992). In other words, non-redundant actors which can reduce the path length among actors in the network affect the efficiency of them. This can improve delivery time and increase agility and responsiveness to market demand and uncertainty (Um and Kim, 2019). Therefore, efficiency improvements are accessible by better coordinating and streamlining the information, activities, and processes in supply chains (Cao and Zhang, 2011).

Effectiveness. Companies are able to enhance their effectiveness through their collaborative networks (Peters et al., 2010). In fact, feedback from the partners such as suppliers enabled the actors like manufacturers to improve the effectiveness of its manufacturing resource planning system (Larson, 1991). In other study, Ledwoch et al. (2018) deduced that effectiveness of the supply chain risk management strategies is moderated by the topology of the supply network and that an increased understanding of supply network topology is necessary to underpin the choice of an 
effective strategy. They also explain that the inventory mitigation strategy proves to be effective for scale-free and random topologies because it always increases fillrates and might decrease costs. However, the amount of cost reduction depends on the network's risk profile and topology.

Innovation acts as an enabler to develop unique products and services that promote competitive advantage for actors. Scholars have stressed how actors belonging to an interorganizational network may improve the learning process both by exchanging pieces of information and by internalizing each other's knowledge (Podolny and Page, 1998). Knowledge assets as a driver of innovation coms from internal knowledge generation and external knowledge sources (Bellamy et al., 2014). In this regard, external knowledge will be acquired through vicarious learning directly or indirectly from other actors in the network (Hora and Klassen, 2013). Thus, align with social network theorists who emphasize on knowledge and information assets derived from structural relationships among as the sources which enhance innovation, there is an argument that supply chain networks serve as important conduits and sources of information and knowledge access, and act as catalysts for the development and dissemination of new ideas, applications, and supply chain practices (Bellamy et al., 2014). For example, Bellamy et al. (2014) in their research examined the structural characteristics of supply networks and concluded that interconnected supply networks strengthen the association between supply network accessibility and innovation output. Moreover, the influence of the two structural characteristics including accessibility and interconnectedness on innovation output can be enhanced by a firm's absorptive capacity and level of supply network partner innovativeness. Another scholar such as Ahuja (2000) showed that innovation rate is positively related to the number of relations with other actors where interconnected themselves.

Sustainability. The Resource-based view (RBV) theory suggests that a firm can create sustainable and competitive advantage through the exploitation of resources (e.g., core competence, dynamic capability, absorptive capacity) from its external partners in a unique way (Barney, 1991). The combination of idiosyncratic resources from the partnering firms can produce unique, valuable, and inimitable resources, thus providing competitive advantage (Barney, 1991; Cao and Zhang, 2011). According to RBV, a buying firm can strengthen core values by investing in relation-specific assets and exploiting resources, knowledge, and know-how of its key suppliers, all of which make it challenging for its competitors to imitate (Cao and Zhang, 2011; Fawcett et al., 2015; Jap, 2001). This view explains that a buying firm's superiority can be yielded through heterogeneity (Cao and Zhang, 2011; Um and Kim, 2019).

Legitimacy and Status advantages are those benefits that are more easily connected to the theory of social capital and to the interpretation of networks as prisms of the market. The point made by scholars investigating these issues is that being connected to peers with specific characteristics (e.g. high status, large available resources) may increase legitimacy at both the organizational and the interorganizational levels (Podolny and Page, 1998). Stuart et al. (1999), for example, found evidence of the fact that affiliation with a prominent alliance partner increases the market value (initial public offering) of a biotechnology firm. They were able to disentangle the effects of resource exchange and transfer of legitimacy, demonstrating "that much of the benefit of having prominent affiliates stems from the transfer of 
status that is an inherent byproduct of inter-organizational associations" (p. 315). Another study, by Stuart (2000), found that alliances can act as endorsements, in particular when small, young firms are associated with high-status peers: third parties have more confidence in the quality and value of the small firm thanks to its network of relationships. Even more interesting for is the study by Baum and Oliver (1991), which focused on legitimacy benefits at the whole-network level. The novelty with respect to other studies on the subject is the claim that externalities of links to high-status actors extend to the whole firm's population (Podolny and Page, 1998; Moretti, 2017).

\section{A Systematic Literature Review on the Supply Chain Network Metrics}

The main goal of this systematic literature review is to identify, screen, and categorize all "articles" that incorporates network analysis in the supply chain and supply chain network contexts which have focused on the behavior and benefits of actors and the network as a whole. To this aim, we followed a process by Colicchia and Strozzi (2012) and Wetzstein et al., (2019) through three stages to accomplish this systematic literature review (Figure 3 ).

\begin{tabular}{|l|l|l|l|}
\hline \multicolumn{5}{|c|}{ Data retrieval (Sample articles) } \\
\hline A) Setting database & B) Searching protocol & C) Selecting time period & D) Screening criteria \\
\hline \multicolumn{3}{|c|}{ Analysis and synthesis } \\
\hline Visualization & Summarization & Integration \\
\hline
\end{tabular}

Fig. 3. Overview of systematic literature review methodology

\subsection{Data Retrieval}

To extract the literature as our sample data, we need to identify a replicable and transparent (Cook et al., 1997) scholarly database with high-quality studies in the leading journals. To this aim, we selected the Scopus scholarly database for its advantages compared to other databases like Google Scholar and Web of Science (Mongeon and Paul-Has, 2016; Harzing and Alakangas, 2017). Then, to ensure a transparent and unbiased process of extracting relevant articles, we used a keyword searching protocol". This protocol concentrates on "Supply chain(s)" "Supply network(s)", and "Supply chain network(s)" as our main keywords for contexts and

\footnotetext{
${ }^{1}$ ( TITLE-ABS-KEY ( "supply chain*" OR "supply network*" OR "supply chain network*" OR "interfirm*" ) ) AND ( TITLE-ABS-KEY ( "network structure" OR "net-
} 
considers network analysis view through incorporating "Network structure", "Network theory", "Network", and "Network analysis" keywords. In addition, align with the main aim of this literature review to investigate those characteristics of organization as unit of analysis which affect its behavior and outcomes through the lens of network analysis, we added the main keywords which is related to the potential advantages of inter-organizational networks including "Performance", "Effectiveness", "Sustainability", "Outcome", "Efficiency", and "Innovation". In this searching protocol, we just focused on peer reviewed articles with excluding all conference papers, book chapters, reviews and reports, books, editorials, and notes. This exclusion is for the purpose of increasing methodological standards and concentrating on the forefront contributions by experts in the field (Colicchia and Strozzi, 2012; Wetzstein et al., 2016). In order to perform our systematic literature review, setting a time period is essential for data analysis (Wetzstein et al., 2019). The analytical results in Figure 4 illustrates the corresponding trend of articles by time with 5062 records in this realm after the searching keywords, starting from 1970 to 2020.

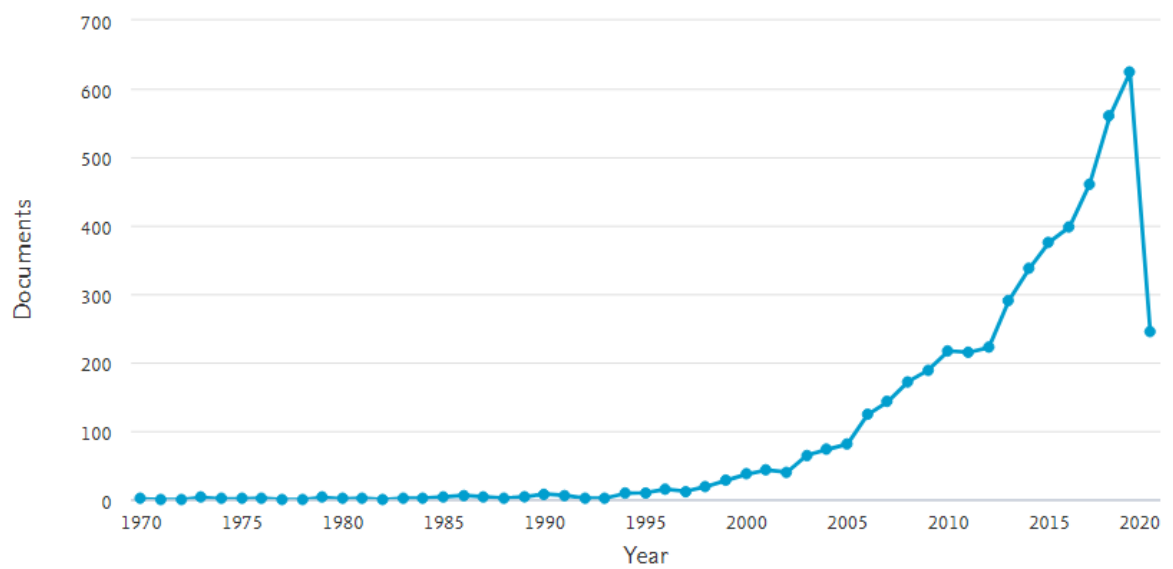

Fig. 4. Supply chain and supply chain network documents, incorporating network view by year (Scopus analytical results)

Figure 2 illustrates that this realm of study in the time span of 1970 and 2020 started to become a hot topic with a sharp increasing trend among the scholars approximately from 1998 with around 20 papers.

However, this time span includes many irrelevant records in our sample selection. So, for better analyzing and integrating the data and exclusively focusing on the studies with highest fit to the scope of this literature review, we needed some criteria for further screening (Wetzstein et al., 2019). To this aim and to ensure a high-quality standard of our literature review, we focused on high-quality articles from the leading journals of the topic under study with minimum score of '3' (based on Association of Business Schools' (ABS) Academic Journal Quality Guide ranking within UK business schools) (Walker et al., 2019; Wetzstein et al., 2019) which

work theory" OR "network analysis" OR "network")) AND ( TITLE-ABS-KEY ( "performance" OR "effectiveness" OR "sustainability" OR "outcome" OR "efficiency" OR "innovation" ) ) AND ( LIMIT-TO ( DOCTYPE , "ar" ) ) 
are in the fields of "General Management, Ethics, Corporate Social Responsibility", "International Business and Area Studies", "Innovation", "Operations and Technology Management", "Operations Research and Management Science", "Organizational Studies", "Social Sciences", and "Strategy". This screening stage, limited the primary records to 753 articles for further analysis. The distribution of these articles per each journal has been presented in Table 3 which demonstrates the contribution of these leading journals in this field of study. Following Wetzstein et al. (2019) in the next step of screening stage, we read the abstracts of these articles which depict an overview of the paper to exclude the articles that did not meet the main aim of this literature review. Then, by considering the final selected papers we read their contributions and identified the main network analysis metrics in order to integration.

Table 3. Distribution of the articles with respect to journals, focusing on network analysis

\begin{tabular}{|c|c|c|c|}
\hline Journal title & $\begin{array}{l}\text { No. } \\
A^{*}\end{array}$ & Journal title & $\begin{array}{l}\text { No. } \\
A^{*}\end{array}$ \\
\hline Administrative science quarterly & 3 & Journal of management studies & 2 \\
\hline Annals of operations research & 39 & Journal of operations management & 25 \\
\hline Antipode & 1 & $\begin{array}{l}\text { Journal of product innovation manage- } \\
\text { ment }\end{array}$ & 6 \\
\hline British journal of management & 2 & Journal of scheduling & 2 \\
\hline Business ethics quarterly & 1 & Journal of supply chain management & 21 \\
\hline $\begin{array}{l}\text { Computational optimization and } \\
\text { applications }\end{array}$ & 2 & $\begin{array}{l}\text { Journal of the operational research soci- } \\
\text { ety }\end{array}$ & 20 \\
\hline Computers and operations research & 29 & Journal of world business & 1 \\
\hline Computers in industry & 11 & Long range planning & 1 \\
\hline Decision sciences & 12 & Management science & 11 \\
\hline Economic geography & 5 & $\begin{array}{l}\text { Manufacturing and service operations } \\
\text { management }\end{array}$ & 4 \\
\hline $\begin{array}{l}\text { European journal of operational re- } \\
\text { search }\end{array}$ & 65 & Naval research logistics & 5 \\
\hline Harvard business review & 1 & New political economy & 2 \\
\hline Industrial and corporate change & 2 & Omega & 6 \\
\hline International business review & 3 & Operations research & 11 \\
\hline $\begin{array}{l}\text { International journal of manage- } \\
\text { ment reviews }\end{array}$ & 1 & Organization science & 7 \\
\hline $\begin{array}{l}\text { International journal of operations } \\
\text { and production management }\end{array}$ & 31 & Organization studies & 1 \\
\hline $\begin{array}{l}\text { International journal of production } \\
\text { economics }\end{array}$ & 140 & Production and operations manag & 9 \\
\hline
\end{tabular}




\begin{tabular}{llll}
\hline $\begin{array}{l}\text { International journal of produc- } \\
\text { tion research }\end{array}$ & 136 & Production planning and control & 48 \\
\hline Journal of business ethics & 5 & R and d management & 4 \\
\hline Journal of business research & 7 & $\begin{array}{l}\text { Reliability engineering and system } \\
\text { safety }\end{array}$ & 5 \\
\hline Journal of development studies & 3 & $\begin{array}{l}\text { Research in the sociology of organiza- } \\
\text { tions }\end{array}$ & 1 \\
\hline Journal of economic geography & 3 & Research policy & 6 \\
\hline $\begin{array}{l}\text { Journal of heuristics } \\
\text { Journal of international manage- } \\
\text { ment }\end{array}$ & 1 & Strategic management journal & 15 \\
\hline Journal of management & 2 & World development & 3 \\
\hline
\end{tabular}

${ }^{*}$ Note: No. A: Number of articles.

Therefore, through this unbiased search with high quality of results we can address the final targeted papers for the analysis and synthesis.

\subsection{Analysis and Synthesis}

To analyze and synthesize the targeted articles, we tried to focus on the most important properties and the related categories. In traditional studies for investigating sources of interfirm differences in competition, the focus was simply on strategic variables like scale, advertising intensity, product similarity and interdependence along value chains (e.g., Porter, 1980). However, actors which have occupied similar positions in the interfirm networks face more intensive competition, and this leads to consider the organizational position within the networks as another critical element of competition (Gulati et al., 2002).

In this regard, following the study of Wasserman and Faust (1994) as one of the basic sources for many researchers who investigate research questions in the context of network using network theory framework, we need to attention that the attributes of actors (e.g., size, age, productivity, etc.) in the network are secondary and relational ties are primary. In other words, attributes of actors are understood in terms of network structure and corresponding patterns of ties among actors. Hence, researchers can also directly study these patterns without referring to attributes of actors in implementing a network viewpoint.

This literature review in investigating sources of interfirm differences with network analysis illustrates that there are a lot of characteristics which have been used to study the behavior and performance of actors and the whole network from two atomistic and relational viewpoints (Table 4). Accordingly, with a higher emphasize on relational view, we tried to analyze and synthesize the existent literature with integrating theoretical contributions and developed concepts in three levels of network, node, and tie.

Network-level with concentrating on network structure refers to the overall pattern of relationships within which all actors are embedded. It is also known as structural embeddedness (Gulati and Gargiulo, 1999). Structural network characteristics capture the impact of the structure of relations around actors on their tendency to cooperate with one another and their profitability (Gulati et al., 2000). 
Corresponding scholars (e.g., Choi et al., 2001; Choi and Kim, 2008; Borgati and Li, 2009; Kim et al., 2011) in this realm have identified several characteristics which can influence the behavior and performance of actors in the network and the network as a whole (Table 4).

Tie-level with concentration on relations between actors refers to the set of institutionalized rules and norms that govern appropriate behavior in the network (Gulati et al., 2000). It is also known as relational embeddedness (Gulati and Gargiulo, 1999). These relations are often influenced by the characteristics of network ties which in turn affect the behavior and performance of actors (Granovetter, 1973; Gulati et al., 2000). Corresponding scholars (e.g., Li and Choi, 2009; Borgati and Li, 2009; Kim et al., 2011; Carter et al., 2007; Oke et al., 2008) in this realm have identified several characteristics which can influence the behaviors and performance of actors in the network and the network as a whole (Table 4).

Node-level with concentration on the position of actors in the network structure refers to the positional characteristics rooted in network models of equivalence and centrality that capture the "roles" actors occupy in a network which affect their behavior and performance and the network as a whole (Gulati et al., 2000). It is also known as positional embeddedness (Gulati and Gargiulo, 1999). Corresponding scholars (e.g., Kim et al., 2011; Li and Choi, 2009; Borgati and Li, 2009; Vereecke et al., 2006) in this realm have identified several characteristics which can influence the behavior and performance of actors in the network and the network as a whole (Table 4).

\section{Positions and Roles}

In network studies there are a broad range of research which have paid to study of positions that are associated with the sociological concept of "role" and "status" (Kinnie et al., 2005). In the social networks, the focus is on properties of social actors for defining the notion of social role in associated with social position from the theoretical, conceptual, and formal viewpoints. While, in the network contexts, the focus is on associations among relations to define network role as the collections of relations and the associations among relations that connect network positions (Wasserman and Faust, 1994).

Studies like Majumder and Srinivasan (2008) and Dittrich and Duysters (2007) have investigated the leading behavior of actors in network positions based on the network characteristics such as centralization and tie strength, respectively. The position of an actor in the network can influence on its behavior and performance (Gulati and Gargiulo, 1999). These advantages which are resulted from corresponding network structural characteristics such as centrality of actor's position and power have been acknowledged in several studies (e.g., Gulati et al., 2000; Bellamy et al., 2014; Sanou et al., 2016). These studies are following network theory suggestion that the role and status of actors in the network are based on their structural relations and is measurable through their positions in the network structure. 
Table 4. Influential characteristics on actors' behavior and performance within the network through the lens of network analysis

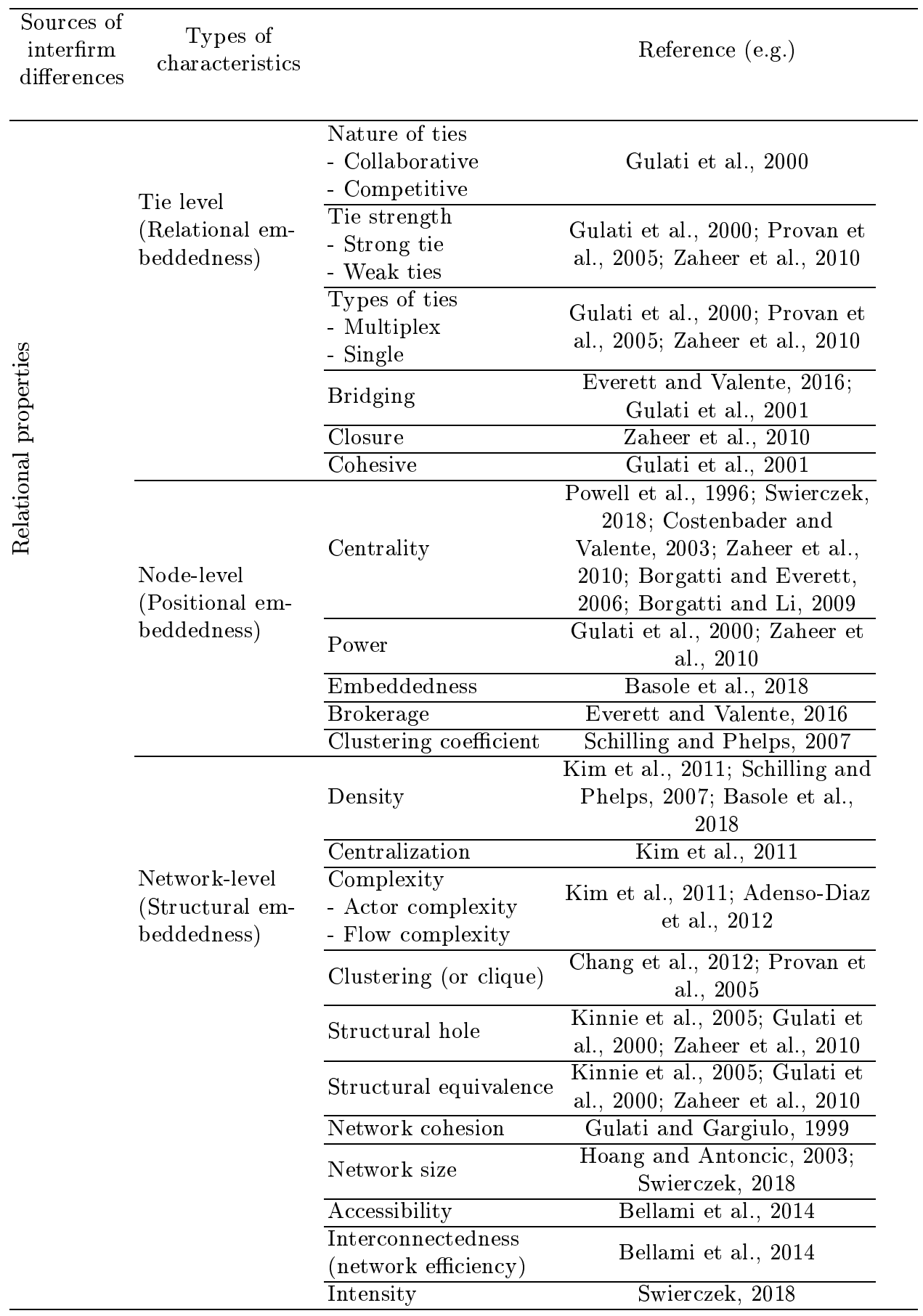




\begin{tabular}{|c|c|c|c|}
\hline \multirow{7}{*}{ 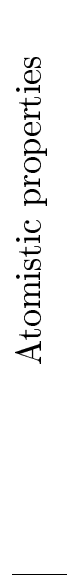 } & \multirow{7}{*}{$\begin{array}{l}\text { Actor's attribu- } \\
\text { tes (Strategic } \\
\text { variables) }\end{array}$} & Organizational size & $\begin{array}{c}\text { Kilduff and Brass, Bellami } \\
\text { et al., 2014; Wasserman and } \\
\text { Faust, 1994; Segev, 1989; } \\
\text { Gulati et al., 2002 }\end{array}$ \\
\hline & & Organizational age & $\begin{array}{c}\text { Segev, 1989; Gulati et al., } \\
2002\end{array}$ \\
\hline & & $\begin{array}{l}\text { Operational effi- } \\
\text { ciency }\end{array}$ & $\begin{array}{c}\text { Kilduff and Brass, 20; } \\
\text { Wasserman and Faust, } \\
\text { 1994; Segev, } 1989\end{array}$ \\
\hline & & Profitability & Porter, 1980; Segev, 1989 \\
\hline & & Quality & Porter, 1980; Segev, 1989 \\
\hline & & Product similarity & $\begin{array}{c}\text { Gulati et al., 2000; Porter, } \\
\text { 1980; Segev, } 1989\end{array}$ \\
\hline & & Etc. & \\
\hline
\end{tabular}

Organizations in the central positions with a large number of ties have better information about potential partners in the network which provide them with collaborative opportunities, hence lowering their level of uncertainty about partnerships (Gulati 1999; Powell et al. 1996). This information advantages are complemented by actor's visibility in central positions, and in uncertain environment these two signaling properties represents the reputation of actors in the network which can be extended beyond its direct ties to indirect ties (Podolny 1993; Kinnie et al., 2005).

Therefore, to study actor's role in the network context, considering it from multiple levels and related characteristics will provide a fruitful theoretical contribution. Accordingly, in this research we will first focus on the position of actors in the network structure from the relational viewpoint, and second, from the associations between relations and the content of relations. Pure structural analysis cause to treat various types of relations among actors as more or less equivalent as the network structure is pivotal comparing to the content of ties (Kilduff and Brass, 2010). Also, various types of relations are often aggregated together to a structural tie (Burt, 1992). However, various types of relations among actors leads to various effects (Podolny and Baron, 1997; Labianca and Brass, 2006). Studies like Dyer and Singh (1998) and Gulati et al. (2002) argue that structural and relational characteristics of organizations drive value from the supply chain network for them. The structural characteristics focus on the position of organizations in the network and the consequent benefits such as resource advantage, resource spillovers, information accessibility etc. However, the relational characteristics focus on the ties and the type of influence on the partners. Accordingly, the performance of each organization depends on its ability to exploit these interactive characteristics in a way that enhances its influence and control over other actors.

Therefore, considering the content of relationships between actors may leads to their different behavior and performance even with identical network structure (Kilduff and Brass, 2010). Accordingly, to study of any roles in the network contexts such as supply chain network and their influence on the actor's performance it is necessary to investigate it through considering the network structural viewpoint and the content of relations. Finally, some atomistic properties could help us as control variables to reach more valid results in order to compare actors and corresponding roles in the inter-organizational relationships. Among these three properties for investigation of roles, we have identified influential network structural properties and 
atomistic properties. However, the content of relationships has been not explained yet which calls for more clarification.

The content of relationships corresponding to the roles which actors play is inherently based on the behavior of actors toward each other and the nature of relationships in the context. In other words, the content of relationships in a specific context is comprised of the behavior that may indicate role of actors (Cloyd, 1964; Nooteboom and Stam, 2008, p.307; Gleave et al., 2009; Prior and Marcos-Cuevas, 2016).

\subsection{Network Centrality}

In this section we want to focus on the key node-level social network analysis metrics and in particular centrality to discuss how this metric can be used to interpret different roles in supply chain networks. Centrality is one of the most studied concepts in social network analysis (Borgatti, 2005). Network centrality refers to the extent to which an actor occupies a position in the network which is relatively known as the most important, prominent, and strategic position. The importance, prominence, and strategic terms are perceived differently in the literature which led to various measures of centrality (Borgatti and Everett, 2006; Kiss and Bichler, 2008; Vurro et al., 2009; Zaheer et al., 2010; Kim et al., 2011; Sanou et al., 2016). For example, the more the centrality, the more status (Bonacich, 1972), the more power (Ibarra, 1993), the more prestige (Burt, 1982), the more accessibility (Bellami et al., 2014), etc. (Table 5).

The concept of network centrality addresses the position of a actors in relation to other actors in a network (see Bloch et al., 2017; Borgatti and Li, 2009; Wasserman and Faust, 1994). The position of an actor in the network can influence on its behavior and performance (Gulati and Gargiulo, 1999). These advantages which are resulted from corresponding network structural characteristics such as centrality of actor's position have been acknowledged in several studies (e.g., Gulati et al., 2000; Bellamy et al., 2014; Sanou et al., 2016; Ibarra, 1993). These studies are following network theory suggestion that the role of actors in the network are based on their structural relations and is measurable through their positions in the network structure. Scholars believe that a central position of actors illustrates their capability to locate, access and disperse valuable information and resources, thereby enhancing performance (Borgatti, 2005; Tsai, 2001).

For example, Ibarra (1993) indicates that network centrality with considering interactions among actors in a network structure has an important effect on roles and in particular innovation role where centrality addresses the structural source of power and determines the degrees of access to and control over valued resources. Organizations in the central positions with a large number of ties have better information about potential partners in the network which provide them with collaborative opportunities, hence lowering their level of uncertainty about partnerships (Gulati, 1999; Powell et al., 1996). This information advantages are complemented by actor's visibility in central positions, and in uncertain environment these two signaling properties represents the reputation of actors in the network which can be extended beyond its direct ties to indirect ties (Podolny, 1993; Kinnie et al., 2005).

Table 5 illustrates an overview of key centrality metrics and corresponding implications for network roles in the context of modeling supply networks. Understanding the situations and the purpose of the study in the supply chain network can contribute to the selection of the best alternative in our analysis. 
Table 5. Main centrality measures and relevant applications (Freeman, 1979; Ballester et al., 2006; Bloch et al., 2017; Kim et al., 2011)

\begin{tabular}{|c|c|c|}
\hline $\begin{array}{l}\text { Centrality } \\
\text { measures }\end{array}$ & Definition & Application \\
\hline $\begin{array}{l}\text { Degree } \\
\text { centrality }\end{array}$ & $\begin{array}{l}\text { When an actor is connected to a highest number of nodes. } \\
\text { It refers to the extent to which an organization has an } \\
\text { impact on operational decisions or strategic behavior of } \\
\text { other actors in the supply chain network. }\end{array}$ & $\begin{array}{l}\text { Visibility/ } \\
\text { Coordinator }\end{array}$ \\
\hline $\begin{array}{l}\text { Indegree } \\
\text { centrality }\end{array}$ & $\begin{array}{l}\text { The degree of difficulty faced by an organization in man- } \\
\text { aging incoming material flows from the upstream actors } \\
\text { in the supply chain network. }\end{array}$ & Integrator \\
\hline $\begin{array}{l}\text { Outdegree } \\
\text { centrality }\end{array}$ & $\begin{array}{l}\text { The degree of difficulty faced by an organization in dealing } \\
\text { with demands from the downstream actors in the supply } \\
\text { chain network. }\end{array}$ & Allocator \\
\hline $\begin{array}{l}\text { Closeness } \\
\text { centrality }\end{array}$ & $\begin{array}{l}\text { When an actor can quickly reach all the other actors, di- } \\
\text { rectly and indirectly. It refers to the extent to which an or- } \\
\text { ganization has freedom from the controlling actions of oth- } \\
\text { ers in terms of accessing information in the supply chain } \\
\text { network. }\end{array}$ & $\begin{array}{l}\text { Independency/ } \\
\text { Navigator }\end{array}$ \\
\hline $\begin{array}{c}\text { Betweenness } \\
\text { centrality }\end{array}$ & $\begin{array}{l}\text { When an actor connects other actors with highest capac- } \\
\text { ity to control interactions among them. It refers to the } \\
\text { extent to which an organization can intervene or has con- } \\
\text { trol over interactions among other actors in the supply } \\
\text { chain network. } \\
\text { Betweenness centrality also refers to the extent to which } \\
\text { an organization affect the final assembler's operational } \\
\text { performance in terms of product quality, coordination } \\
\text { cost, and overall lead-time. }\end{array}$ & $\begin{array}{l}\text { Influence/ } \\
\text { Broker } \\
\text { Pivotal }\end{array}$ \\
\hline $\begin{array}{l}\text { Katz- } \\
\text { Bonacich } \\
\text { centrality }\end{array}$ & $\begin{array}{l}\text { It counts the number of paths that stem from an actor } \\
\text { exponentially discounted based on the length of paths. }\end{array}$ & Prestige \\
\hline Intercentrality & $\begin{array}{l}\text { It counts the total number of such paths that hit the ac- } \\
\text { tor; it is the sum of the actor's Katz-Bonacich centrality } \\
\text { and the actor's contribution to every other actor' Katz- } \\
\text { Bonacich centrality. }\end{array}$ & $\begin{array}{l}\text { Collective } \\
\text { contribution }\end{array}$ \\
\hline $\begin{array}{c}\text { Eigenvector } \\
\text { centrality }\end{array}$ & Sum of centrality of neighbors. & Prestige \\
\hline $\begin{array}{l}\text { Diffusion } \\
\text { centrality }\end{array}$ & $\begin{array}{l}\text { The expected number of times that actors have been con- } \\
\text { tacted is computed using the number of walks. }\end{array}$ & Diffusion \\
\hline
\end{tabular}


Game-theoretic centrality measure. Social network analysis methods are applied in many other fields such as economics, physics, information technologies, etc. (Avrachenkov et al., 2015). Supply chain network is one of the areas which social network analysis can be applied to study the roles and positions of actors or organizations in relation with each other (Kim et al., 2011). Supply chain networks can be visualized based on the social exchanges among actors and using graphs. Graph theory provides main analysis tools for networks (Martínez-López et al., 2009). In particular, by calculating centrality measures for actors or nodes one may detect active actors (organization) of a supply chain network.

Community detection refers to the procedure of identifying groups of interacting nodes (i.e., actors) in a network depending upon their structural properties. It has been used to unveil the structural properties and behaviors of networks as well as actors in the network (Javed et al., 2018). Avrachenkov et al. (2018) indicates the importance of using game theory, and in particular, coalition game theory for community detection problem. They introduced cooperative game theory approach to explain possible mechanisms behind cluster formation. This approach is based on the Myerson value in cooperative game theory, which particularly emphasizes the value allocation in the context of games with interactions between players constrained by a network. In this research we can implement their method in a supply chain network context where actors cooperate with each other to fulfill customer's needs.

Myerson cooperative game approach (Avrachenkov et al., 2018). In general, a cooperative game of $\mathrm{n}$ actors is a pair $\langle N, v\rangle$ where $N=\{1,2, \ldots, n\}$ is the set of actors and $v: 2^{N} \rightarrow R$ is a map prescribing for a coalition $S \in 2^{N}$ some value $v(S)$ such that $v(\emptyset)=0$. This function $v(S)$ is the total utility that members of $S$ can jointly attain. Such a function is called the characteristic function of cooperative game.

We first need to construct the characteristic function. Each link in the supply chain network context among actors gives to coalition $S$ the value of $r$, where $0<r<1$. Moreover, actors can gain a value from indirect links which can be interpreted based on the length of the simple path $k$. Therefore, for any coalition $S$, we can define the characteristic function as bellow:

$$
v(S)=\sum_{k=1}^{\infty} a_{k}(g, S) \cdot r^{k}
$$

where $a_{k}(g, S)$ is the number of simple paths of length $k$ in the coalition $(S)$. Then the Myerson value of an actor $i$ is given by:

$$
Y_{i}(v, g)=\sum_{k=1}^{\infty} \frac{a_{k}^{(i)}(g, S) \cdot r^{k}}{k+1}
$$

where $a_{k}^{(i)}(g, S)$ is the number of simple paths of length $k$ containing node $i$ in the coalition $S$ defined with graph $g$. The denominator $(k+1)$ is based on the length of the simple paths which are bounded by $n-1$.

Let we consider a supply chain network consist of two suppliers (S), one manufacturer (M), one distributer (D), and two retailers (R) where they have symmetric collaborative links (Figure 5). In this network we have $N=\{1,2,3,4,5\}$ actors. In this cooperative game we find the Myerson value $Y_{i}(v, g)$ for each actor. 


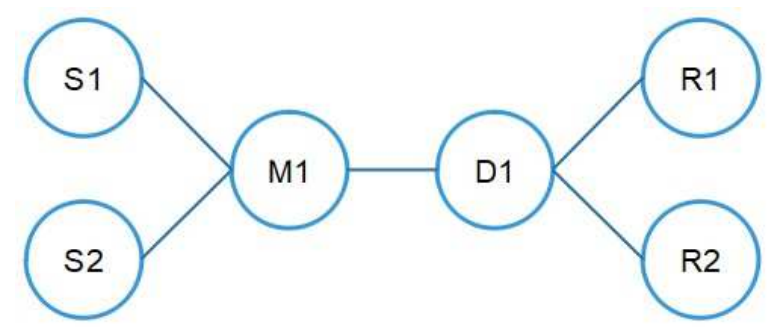

Fig. 5. The structure of supply chain network

According to the Figure 5 we can identify possible paths which contains each specific actor (Table 6).

Table 6. The possible paths which contain the actor $i$

\begin{tabular}{|c|c|c|c|}
\hline $\begin{array}{l}\text { actor } \\
i\end{array}$ & Length 1 & Length 2 & Length 3 \\
\hline S1 & $\{\mathrm{S} 1, \mathrm{M} 1\}$ & $\{\mathrm{S} 1, \mathrm{M} 1, \mathrm{~S} 2\},\{\mathrm{S} 1, \mathrm{M} 1, \mathrm{D} 1\}$ & $\{\mathrm{S} 1, \mathrm{M} 1, \mathrm{D} 1, \mathrm{R} 1\},\{\mathrm{S} 1, \mathrm{M} 1, \mathrm{D} 1, \mathrm{R} 2\}$ \\
\hline$\overline{\mathrm{S} 2}$ & $\{\mathrm{~S} 2, \mathrm{M} 1\}$ & $\{\mathrm{S} 2, \mathrm{M} 1, \mathrm{~S} 1\},\{\mathrm{S} 1, \mathrm{M} 1, \mathrm{D} 1\}$ & $\{\mathrm{S} 2, \mathrm{M} 1, \mathrm{D} 1, \mathrm{R} 1\},\{\mathrm{S} 2, \mathrm{M} 1, \mathrm{D} 1, \mathrm{R} 2\}$ \\
\hline M1 & $\begin{array}{l}\{\mathrm{M} 1, \mathrm{~S} 1\} \\
\{\mathrm{M} 1, \mathrm{~S} 2\} \\
\{\mathrm{M} 1, \mathrm{D} 1\}\end{array}$ & $\begin{array}{l}\{\mathrm{M} 1, \mathrm{D} 1, \mathrm{R} 1\},\{\mathrm{M} 1, \mathrm{D} 1, \mathrm{R} 2\}, \\
\{\mathrm{D} 1, \mathrm{M} 1, \mathrm{~S} 2\},\{\mathrm{D} 1, \mathrm{M} 1, \mathrm{~S} 1\}, \\
\{\mathrm{S} 1, \mathrm{M} 1, \mathrm{~S} 2\}\end{array}$ & $\begin{array}{l}\{\mathrm{S} 2, \mathrm{M} 1, \mathrm{D} 1, \mathrm{R} 2\},\{\mathrm{S} 1, \mathrm{M} 1, \mathrm{D} 1, \mathrm{R} 2\} \\
\{\mathrm{S} 1, \mathrm{M} 1, \mathrm{D} 1, \mathrm{R} 1\},\{\mathrm{S} 2, \mathrm{M} 1, \mathrm{D} 1, \mathrm{R} 1\}\end{array}$ \\
\hline D1 & $\begin{array}{l}\{\mathrm{D} 1, \mathrm{R} 1\} \\
\{\mathrm{D} 1, \mathrm{R} 2\} \\
\{\mathrm{D} 1, \mathrm{M} 1\}\end{array}$ & $\begin{array}{l}\{\mathrm{D} 1, \mathrm{M} 1, \mathrm{~S} 1\},\{\mathrm{D} 1, \mathrm{M} 1, \mathrm{~S} 2\}, \\
\{\mathrm{M} 1, \mathrm{D} 1, \mathrm{R} 2\},\{\mathrm{M} 1, \mathrm{D} 1, \mathrm{R} 1\}, \\
\text { R1, D1, R2 }\}\end{array}$ & $\begin{array}{l}\{\mathrm{S} 2, \mathrm{M} 1, \mathrm{D} 1, \mathrm{R} 2\},\{\mathrm{S} 1, \mathrm{M} 1, \mathrm{D} 1, \mathrm{R} 2\} \\
\{\mathrm{S} 1, \mathrm{M} 1, \mathrm{D} 1, \mathrm{R} 1\},\{\mathrm{S} 2, \mathrm{D} 1, \mathrm{D} 1, \mathrm{R} 1\}\end{array}$ \\
\hline $\mathrm{R} 1$ & $\{\mathrm{R} 1, \mathrm{D} 1\}$ & $\{\mathrm{R} 1, \mathrm{D} 1, \mathrm{R} 2\},\{\mathrm{R} 1, \mathrm{D} 1, \mathrm{M} 1\}$ & $\{\mathrm{R} 1, \mathrm{D} 1, \mathrm{M} 1, \mathrm{~S} 1\},\{\mathrm{R} 1, \mathrm{D} 1, \mathrm{M} 1, \mathrm{~S} 2\}$ \\
\hline$\overline{\mathrm{R} 2}$ & $\{\mathrm{R} 2, \mathrm{D} 1\}$ & $\{\mathrm{R} 2, \mathrm{D} 1, \mathrm{R} 1\},\{\mathrm{R} 1, \mathrm{D} 1, \mathrm{M} 1\}$ & $\{\mathrm{R} 2, \mathrm{D} 1, \mathrm{M} 1, \mathrm{~S} 1\},\{\mathrm{R} 2, \mathrm{D} 1, \mathrm{M} 1, \mathrm{~S} 2\}$ \\
\hline
\end{tabular}

Then with calculation of Myerson value for each actor (Table 7) using $r=0.5$ we can rank active actors which can be interpreted as coordinator, integrator, or leader in the supply chain network context.

Table 7. Myerson value for each actor $i$

\begin{tabular}{cc}
\hline actor $\boldsymbol{i}$ & Myerson value \\
\hline S1 & 1.25 \\
\hline S2 & 1.25 \\
\hline M1 & $\mathbf{3 . 2 5}$ \\
\hline D1 & $\mathbf{3 . 2 5}$ \\
\hline R1 & 1.25 \\
\hline R2 & 1.25 \\
\hline
\end{tabular}

The results illustrate that manufacturer and distributer have the highest Myerson value in the supply chain network context. 


\section{Conclusion and Future Research}

In the supply chain network, each actor is engaged in a set of exchange interorganizational relationships which defines the network structure. To have a fruitful theoretical contribution corresponding to the actors' role and their positions with related characteristics and outcomes it is necessary to take a multilevel analysis perspective. First, a behavioral expectation related to a given position in network structure highlights the importance of relational attributes in terms of node level, tie level and network level characteristics of organizations. Second, the emergent view of role highlights the content of relationships corresponding to the roles which actors play and it is inherently based on the style of behavior toward each other and the nature of relationships among organizations. It also emphasizes on the atomistic properties of actors in the network which affect their role toward other actors.

Therefore, for future study we propose to investigate any role such as leader and follower roles among supply chain network members using this framework through a multilevel analysis approach considering the relational and emergent aspects of role.

\section{References}

Adenso-Diaz, B., Mena, C., García-Carbajal, S., Liechty, M. (2012). The impact of supply network characteristics on reliability. Supply Chain Management, 17(3), 263-276.

Ahuja, G. (2000). Collaboration networks, structural holes, and innovation: A longitudinal study. Administrative Science Quarterly, 45(3), 425-455.

Akyuz, G. A. and Erkan, T. E. (2010). Supply chain performance measurement: a literature review. International Journal of Production Research, 48(17), 5137-5155.

Alexander, E. R. (1995). How Organizations Act Together: Interorganizational Coordination in Theory and Practice, Gordon and Breach Science Publishers SA. Luxemburg. 408 pages.

Anderson, H., Havila, V., Andersen, P., Halinen, A. (1998). Position and roleconceptualizing dynamics in business networks Author links open overlay. Scandinavian Journal of Management, 14(3), 167-186.

Avrachenkov, K. E., Mazalov, V.V., Tsynguev, B. T. (2015). Beta Current Flow Centrality for Weighted Networks. In: Thai M., Nguyen N., Shen H. (eds) Computational Social Networks. CSoNet 2015. Lecture Notes in Computer Science, vol 9197. Springer, Cham

Avrachenkov, K. E., Kondratev, A. Y., Mazalov, V. V., Rubanov, D. G. (2018). Network partitioning algorithms as cooperative games. Computational Social Networks, 5(11), $1-28$.

Baker, W. E. and Faulker, R. R. (1991). Role as resource in the Hollywood film industry. American Journal of Sociology, 97, 279-309.

Ballester, C., Calvó-Armengol, A., Zenou, Y. (2006). Who's Who in Networks. Wanted: The Key Player. Econometrica, 74, 1403-1417.

Balkundi, P. and Kilduff, M. (2006). The ties that lead: A social network approach to leadership. The Leadership Quarterly, 17, 419-439.

Barney, J. (1991). Firm resources and sustained competitive advantage. Journal of management, 17(1), 99-120.

Basole, R. C., Ghosh, S., Hora, M. S. (2018). Supply Network Structure and Firm Performance: Evidence From the Electronics Industry. IEEE Transactions on Engineering Management, 65(1), 141-154.

Basole, R. C., Rouse, W., McGinnis, L. F., Bodner, D. A., Kessler, W. C. (2011). Models of complex enterprise networks. Journal of Enterprise Transformation, 1(3), 208-230.

Baum, J. A. C. and Oliver, C. (1991). Institutional Linkages and Organizational Mortality. Administrative Science Quarterly, 36(2), 187-218. 
Bellamy, M. A. and Basole, R. C. (2013). Network Analysis of Supply Chain Systems: A Systematic Review and Future Research. Systems Engineering, 16(2), 235-249.

Bellamy, M. A., Ghosh, S., Hora, M. (2014). The influence of supply network structure on firm innovation. Journal of Operations Management, 32, 357-373.

Bloch, F., Jackson, M. O., Tebaldi, P. (2017). Centrality Measures in Networks, arXiv:1608.05845v3, 1-37.

Borders, A. L., Johnston, W. J., Rigdon, E. E. (2001). Beyond the Dyad: Electronic Commerce and Network Perspectives in Industrial Marketing Management. Industrial Marketing Management, 30, 199-205.

Borgatti, S. P. and Everett, M. G. (2006). A Graph-theoretic perspective on centrality. Social Networks, 28, 466-484.

Borgatti, S. P. and Halgin, D. S. (2011). On Network Theory. Organization Science, 22(5), 1168-1181.

Borgatti, S. P. and Li, X. (2009). On social network analysis in a supply chain context. Journal of Supply Chain Management, 45(2), 5-22.

Borgatti, S. P. (2005). Centrality and network flow. Social Networks, 27, 55-71.

Borgatti, S. P., Mehra, A., Brass, D. J., Labianca, G. (2009). Network analysis in the social sciences. Science, 323, 892-895.

Burkhardt, M.E. and Brass, D. J. (1990). Changing patterns or patterns of change: the effects of a change in technology on social network structure and power. Administrative Science Quarterly, 35, 104-127.

Burt, R. S. (1983). Corporate Profits and Cooptation: Networks of Market Constraints and Directorate Ties in the American Economy. Academic Press, New York.

Burt, R. S. (1992). Structural holes: The social structure of competition. Cambridge, MA: Harvard University Press.

Burt, R.S. (1982). Toward a Structural Theory of Action. Academic Press, New York.

Camarihna-Matos, L. M., and Afsarmanesh, H. (2008). Concept of Collaboration. In G. Putnik, \& M. Cruz-Cunha (Eds.). Encyclopedia of Networked and Virtual Organizations, 311-315. Hershey, PA: IGI Global.

Cao, M. and Zhang, Q. (2011). Supply chain collaboration: Impact on collaborative advantage and firm performance. Journal of Operations Management, 29, 163-180.

Carter, C.R., Ellram, L. M., Tate, W. (2007). The use of social network analysis in logistics Research. Journal of Business Logistics, 28(1), 137-169.

Carter, C. R., Rogers, D. S., Choi, T. Y. (2015). Toward the Theory of the Supply Chain. Journal of Supply Chain Management, 51, 89-97.

Chang, C-W., Chiang, D.M., Pai, F-Y. (2012). Cooperative strategy in supply chain networks. Industrial Marketing Management, 41, 1114-1124.

Cheng, J. L. C. (1983). Interdependence and Coordination in Organizations: A Role-System Analysis. Academy of Management Journal, 26(1), 156-162.

Chiesi, A. M. (2001). Network Analysis, Editor(s): Neil J. Smelser, Paul B. Baltes, International Encyclopedia of the Social \& Behavioral Sciences, Pergamon, 10499-10502.

Choi, T. Y. and Kim, Y. (2008). Structural embeddedness and supplier management: a network perspective. Journal of Supply Chain Management, 44, 5-13.

Choi, T. Y. and Wu, Z. (2009). Taking the leap from dyads to triads: Buyer-supplier relationships in supply networks. Journal of Purchasing \& Supply Management, 15, 263266.

Choi, T. Y., Dooley, K. J., Rungtusanatham, M. (2001). Supply networks and complex adaptive systems: control versus emergence. Journal of Operations Management, 19(3), 351-366.

Chopra, S. and Meindl, P. (2016). Supply Chain Management: Strategy, Planning, and Operation. (6th ed.) Pearson Education, Essex, NE. 529 pages.

Christopher, M. (1998). Logistics and Supply Chain Management: Strategies for Reducing Cost and Improving Service, $2^{\text {nd }}$ Edition, Financial Times/Prentice Hall, London. 294 pages. 
Cloutier, R., Muller, G., Verma, D., Nilchiani, R., Hole, E., Bone, M. (2010). The concept of reference architectures. System Engineering, 13(1), 14-27.

Cloyd, J. S. (1964). Patterns of Role Behavior in Informal Interaction. Sociometry, 27(2), $161-173$.

Coase, R. H. (1937). The nature of the firm. Economica, 4(16), 386-405.

Coleman, J. S. (1990). Foundations of Social Theory. Cambridge, MA: Harvard, University Press.

Colicchia, C. and Strozzi, F. (2012). Supply chain risk management: a new methodology for a systematic literature review. Supply Chain Management: An International Journal, 17, 403-418.

Cook, D.J., Mulrow, C.D., Haynes, R.B. (1997). Systematic reviews: synthesis of best evidence for clinical decisions. Annals of Internal Medicine, 126, 376-380.

Cornwell, B. (2009). Good health and the bridging of structural holes. Social Networks, 31(1), 92-103.

Costenbader, E. and Valente, T. W. (2003). The stability of centrality measures when networks are sampled. Social Networks, 25, 283-307.

Dahl, R. A. (1957). The concept of power. Behavioral Science, 201-218.

Dittrich, K. and Duysters, G. (2007). Networking as a Means to Strategy Change: The Case of Open Innovation in Mobile Telephony. Journal of Product Innovation Management, 24(6), 510-521.

Dyer, J. H. and Nobeoka, K. (2000). Creating and managing a high-performance knowledgesharing network: the Toyota case. Strategic Management Journal, 21(3), 345-367.

Dyer, J. H. and Singh, H. (1998). The Relational View: Cooperative Strategy and Sources of Interorganizational Competitive Advantage. Academy of Management Review, 23(4), 660-679.

El-Ansary, A. and Stern, L. W. (1972). Power Measurement in the Distribution Channel. Journal of Marketing Research, 9, 47-52.

Ellram, L. M., Tate, W. L., Carter, C. R. (2006). Product-process-supply chain: an integrative approach to three-dimensional concurrent engineering. International Journal of Physical Distribution \& Logistics Management, 37(4), 305-330.

Emerson, R. M. (1962). Power-Dependence Relations. American Sociological Review, $\mathbf{2 7}(\mathbf{1}), 31-41$.

Esmaeili, M. and Zeephongsekul, P. (2010). Seller-buyer models of supply chain management with an asymmetric information structure. International Journal of Production Economics, 123(1), 146-154.

Esmaeili, M., Aryanezhad, M-B., Zeephongsekul, P. (2009). A game theory approach in seller-buyer supply chain. European Journal of Operational Research, 195, 442-448.

Etgar, M. (1976). Channel Domination and Countervailing Power in Distributive Channels. Journal of Marketing Research, 13(3), 254-262.

Everett, M.G. and Valente, T.W. (2016). Bridging, brokerage and betweenness. Social Networks, 44, 202-208.

Everett, M. G., Borgatti, S.P. (1999). The centrality of groups and classes. Journal of Mathematical Sociology, 23(3), 181-201.

Fawcett, S. E., McCarter, M. W., Fawcett, A. M., Webb, G. S., Magnan, G. M. (2015). Why supply chain collaboration fails: the socio-structural view of resistance to relational strategies. Supply Chain Management: An International Journal, 20(6), 648-63.

Freeman, L. C. (1977). A set of measures of centrality based on betweenness. Sociometry, 40, 35-41.

Freeman, L. C. (1979). Centrality in social networks: conceptual clarification. Social Networks, 1, 215-239.

Gleave, E., Welser, H. T., Lento, T. M., Smith, M. A. (2009). A Conceptual and Operational Definition of 'Social Role' in Online Community. 42nd Hawaii International Conference on System Sciences, Big Island, HI, pp. 1-11. 
Gnyawali, D.R., He, J., Madhaven, R. (2006). Impact of co-opetition on firm competitive behaviour: An empirical examination. Journal of Management, 32(4), 507-530.

Granovetter, M. (1973). The strength of weak ties. American Journal of Sociology, 78, $360-1380$

Granovetter, M. (1985). Economic action and social structure: The problem of embeddedness. American Journal of Sociology, 91, 481-510.

Granovetter, Mark S. (1973). The Strength of Weak Ties. American Journal of Sociology, 78(6), 1360-1380.

Gulati, R. (1998). Alliances and network. Strategic Management Journal, 19(4), 293-317.

Gulati, R. and Gargiulo, M. (1999). Where Do Interorganizational Networks Come From? American Journal of Sociology, 104(5), 1439-1493.

Gulati, R., Dialdin, D. A. and Wang, L. (2002). Organizational Networks. In the Blackwell Companion to Organizations, edited by J.A.C. Baum, 281-303. Boston: Blackwell Publishers.

Gulati, R., Lavie, D., Madhavan, R. (2011). How do networks matter? The performance effects of interorganizational networks. Research in Organizational Behavior, 31, 207224.

Gulati, R., Nohria, N., Zaheer, A. (2000). Strategic networks. Strategic Management Journal, 21, 203-215.

Harzing, A. W. and Alakangas, S. (2017). Microsoft Academic: Is the Phoenix getting wings? Scientometrics, 110(1), 371-383.

Heikkinen, M. T., Mainela, T., Still, J., Tähtinen, J. (2007). Roles for managing in mobile service development nets. Industrial Marketing Management, 36, 909-925.

Hoang, H. and Antoncic, B. (2003). Network-based research in entrepreneurship A critical review. Journal of Business Venturing, 18, 165-187.

Hora, M. and Klassen, R. D. (2013). Learning from others' misfortune: factors influencing knowledge acquisition to reduce operational risk. Journal of Operations Management, 31(1), 52-61.

Hosseini-Motlagh, S-M., Nouri-Harzvili, M., Choi, T-M., Ebrahimi, S. (2019). Reverse supply chain systems optimization with dual channel and demand disruptions: Sustainability, CSR investment and pricing coordination. Information Sciences, 503, 606-634

Ibarra, H. (1993). Network centrality, power, and innovation involvement: determinants of technical and administrative roles. Academy of Management Journal, 36, 471-501.

Ingram, P. and Baurn, J. A. C. (1997). Chain affiliation and the failure of Manhattan hotels, 1898-1980. Administrative Science Quarterly, 42, 68-102.

Jap, S. D. (2001). Perspectives on joint competitive advantages in buyer-supplier relationships. International Journal of Research in Marketing, 18(1), 19-35.

Javed, M. A., Younis, M.S., Latif, S., Qadir, J., Baig, A. (2018). Community detection in networks: A multidisciplinary review. Journal of Network and Computer Applications, 108, 87-111.

Jones, C., Hesterly, W. S., Borgatti, S. P. (1997). A General Theory of Network Governance: Exchange Conditions and Social Mechanisms. Academy of Management Review, 22(4), 911-945.

Ketchen Jr., D. J., Hult, G.T.M. (2007). Bridging organization theory and supply chain management: the case of best value supply chains. Journal of Operations Management, 25(2), 573-580.

Kilduff, M. and Brass, D. J. (2010). Organizational Social Network Research: Core Ideas and Key Debates. The Academy of Management Annals, 4(1), 317-357.

Kilduff, M. and Tsai, W. (2003). Social Networks and Organizations. London, UK: Sage Publications.

Kim, Y., Choi, T. Y., Yan, T., Dooley, K. (2011). Structural investigation of supply networks: A social network analysis approach. Journal of Operations Management, 29, $194-211$. 
Kinnie, N. J., Swart, J., Purcell, J. (2005). Influences on the choice of HR system: the network organization perspective. The International Journal of Human Resource Management, 16(6), 1004-1028.

Knight, L. and Harland, C. (2005). Managing supply networks: organizational roles in network management. European Management Journal, 23(3), 281-292.

Knoben, J., Oerlemans, T, L.A.G., Rutten, R.P.J.H. (2006). Radical changes in interorganizational network structures: The longitudinal gap. Technological Forecasting \& Social Change, 73, 390-404.

Kraatz, M.S. (1998). Learning by association? Interorganizational networks and adaptation to environmental change. Academy of Management Journal, 41, 621-643.

Krackhardt, D. (1990). Assessing the political landscape: structure, cognition and power in organization. Administrative Science Quarterly, 35(2), 342-69.

Labianca, G. and Brass, D. J. (2006). Exploring the Social Ledger: Negative Relationships and Negative Asymmetry in Social Networks in Organizations. American Journal of Review, 31(3), 596-614.

Lado, A. A., Boyd, N. G., Hanlon, S.C. (1997). Competition, cooperation, and the search For economic rents: a syncretic model. Academy of Management Review, 22(1), 110141

Lam, C. Y., Chan, S. L., Ip, W. H., Lau, C. W. (2008). Collaborative supply chain network using embedded genetic algorithms. Industrial Management \& Data Systems, 108(8), $1101-1110$.

Larson, A. (1991). Partner networks: leveraging external ties to improve entrepreneurial performance. Journal of Business Venturing, 6, 173-88.

Lazzarini, S. G., Chaddad, F. R., Cook, M. L. (2001). Integrating supply chain and network analyses: the study of netchains. Journal on Chain and Network Science, 1(1), 7-22.

Ledwoch, A., Yasarcan, H., Brintrup, A. (2018). The moderating impact of supply network topology on the effectiveness of risk management. International Journal of Production Economics, 197, 13-26.

Li, M. and Choi, T. Y. (2009). Triads in services outsourcing: Bridge, bridge decay and bridge transfer. Journal of Supply Chain Management, 45(3), 27-39.

Lorenzoni, G. and Lipparini, A. (1999). The leveraging of interfirm relationships as a distinctive organizational capability: a longitudinal study. Strategic Management Journal, 20(4), 317-338.

Majumder, P. and Srinivasan, A. (2008). Leadership and Competition in Network Supply Chains. Management Science, 54(6), 1189-1204.

Malone, T. and Crowston, K. (1994). The interdisciplinary study of coordination. ACM Computing Surveys, 26(1), 87-119.

Marsden, P. V. (2002). Egocentric and sociocentric measures of network centrality. Social Networks, 24(4), 407-422.

Martínez-López, B., Perez, A. M., Sánchez-Vizcaíno, J. M. (2009). Social Network Analysis. Review of General Concepts and Use in Preventive Veterinary Medicine. Transboundary and Emerging Diseases, 56, 109-120.

McEvily, B. and Zaheer, A. (1999). Bridging ties: A source of firm heterogeneity in competitive capabilities. Strategic Management Journal, 20(12), 1133-1158.

Meijer, S. (2009). The organization of transactions: Studying supply networks using gaming simulation, International chains and network series - Volume 6, Wageningen Academic Publisher, Netherlands. 207 pages.

Miles, R. E. and Snow, C. C. (1992). Causes of Failure in Network Organizations. California Management Review, 34(4), 53-72.

Min, H. and Zhou, G. (2002). Supply chain modeling: past, present and future. Computers \& Industrial Engineering, 43(1-2), 231-249

Moliterno, T. P. and Mahony, D. M. (2011). Network Theory of Organization: A Multilevel Approach. Journal of Management, 37(2), 443-467. 
Mongeon, P. and Paul-Hus, A. (2016). The journal coverage of Web of Science and Scopus: A comparative analysis. Scientometrics, 106(1), 213-228.

Moretti, A. (2017). The Network Organization: A Governance Perspective on Structure, Dynamics and Performance. Palgrave Macmillan, Edition 1, 157 Pages.

Nagurney, A. and Li, D. (2016). Competing on Supply Chain Quality: A Network Economics Perspective. Springer, Cham Heidelberg. 383 pages.

Nooteboom, B. and Stam, E. (2008). Micro-foundations for innovation policy. Amsterdam: Amsterdam University Press. 368 pages.

Obstfeld, D. (2005). Social Networks, the Tertius Iungens Orientation, and Involvement in Innovation. Administrative Science Quarterly, 50(1), 100-130.

Oke, A., Idiagbon-Oke, M., Walumbwa, F. (2008). The relationship between brokers' influence, strength of ties and NPD project outcomes in innovation-driven horizontal networks. Journal of Operations Management, 26(5), 571-589.

Oliver, A. L. (2004). On the duality of competition and collaboration: network-based knowledge relations in the biotechnology industry. Scandinavian Journal of Management, 20, 1510171.

Omta, S. W. F., Trienekens, J., Beers, G. (2002). A Research and Management Agenda for Chain and Network Science. Chain and network science, 2(1), 1-5.

Peters, L. D., Pressey, A. D., Westerlund, M., Rajala, R. (2010). Learning and innovation in inter-organizational network collaboration. Journal of Business \& Industrial Marketing, $\mathbf{2 5}(\mathbf{6}), 435-442$.

Pfeffer, J. and Salancik, G. R. (1978). The External Control of Organizations: A Resource Dependence Perspective. New York, NY, Harper and Row.

Pilbeam, C., Alvarez, G., Wilson, H. (2012). The governance of supply networks: a systematic literature review. Supply Chain Management: An International Journal, 17/4, $358-376$

Podolny, J. (1993). A status based model of market competition. American Journal of Sociology, 98, 829-872.

Podolny, J. M. and Baron, J. N. (1997). Relationships and resources: Social networks and mobility in the workplace. American Sociological Review, 62, 673-693.

Podolny, J. M. and Page, K.L. (1998). Network Forms of Organization. Annual Review of Sociology, 24, 57-76.

Polenske, K. (2004). Competition, Collaboration and Cooperation: An Uneasy Triangle in Networks of Firms and Regions. Regional Studies, 38(9), 1029-1043.

Pollock, T. G., Porac, J. F., Wade, J.B. (2004). Constructing deal networks: brokers as network "architects" in the US IPO market and other examples. The Academy of Management Review, 29(1), 50-72.

Porter, M. E. (1980). Competitive Strategy. Free Press, New York.

Portes, A. and Sensenbrenner, J. (1993). Embeddedness and Immigration: Notes on the Social Determinants of Economic Action. American Journal of Sociology, 98(6), 1320 1350 .

Powell, W.W. (1990). Neither market nor hierarchy: network forms of organization. Research in Organizational Behavior, 12, 295-336.

Powell, W. W., Koput K. W., Smith-Doerr L. (1996). Interorganizational collaboration and the locus of innovation: Networks of learning in biotechnology. Administrative Science Quarterly, 41, 116-145.

Powell, W. W., Koput, K. W., Smith-Doerr, L., Owen-Smith, J. (1999). Network Position and Firm Performance: Organizational Returns to Collaboration in the Biotechnology Industry. Research in the Sociology of Organizations, 16, 19-39.

Prior, D.D. and Marcos-Cuevas, J. (2016). Value co-destruction in interfirm relationships. Marketing Theory, 16(4), 533-552.

Provan, K. G., Veazie, M.A., Staten, L. K., Teufel-Shone, N. I. (2005). The Use of Network Analysis to Strengthen Community Partnerships. Public Administration Review, 65(5), 603-613. 
Rapoport, A. (1979). A Probabilistic Approach to Networks. Social Networks, 2, 1-18.

Rudzki, R. A. and Trent, R. J. (2010). Next Level Supply Management Excellence : Your Straight to the Bottom Line Roadmap, J. Ross Publishing Inc. ProQuest E-book Central. 447 pages.

Sanou, F. H., Le Roy, F. and Gnyawali, D. R. (2016). How Does Centrality in Coopetition Networks Matter? An Empirical Investigation in the Mobile Telephone Industry. British Journal of Management, 27, 143-160.

Schilling, M. A. and Phelps, C. C. (2007). Interfirm Collaboration Networks: The Impact of Large-Scale Network Structure on Firm Innovation. Management Science, 53(7), $1113-1126$.

Segev, E. (1989). A systematic comparative analysis and synthesis of two business-level strategic typologies. Strategic Management Journal, 10, 487-505.

Simchi-Levi, D., Kaminsky, P., Simchi-Levi, E. (2000). Designing and Managing the Supply Chain: Concepts, Strategies and Case Studies. Irwin McGraw Hill, Boston, MA.

Snow, C. C. (2017). Organizing in the Age of Competition, Cooperation, and Collaboration. Journal of Leadership and Organizational Studies, 22(4), 433-442.

Stuart, T. E. (2000). Interorganizational Alliances and the Performance of Firms: A Study of Growth and Innovation Rates in a High-Technology Industry. Strategic Management Journal, 21(8), 791-811.

Stuart, T. E., Hoang, H., Hybels, R. C. (1999). Interorganizational Endorsements and the Performance of Entrepreneurial Ventures. Administrative Science Quarterly, 44(2), $315-349$

Swierczek, A. (2018). The inverted U-shaped relationship between the network profile and the competitive advantage of supply chains: Chasing the perfect network setting. International Journal of Logistics Management, 29(4), 1379-1400.

Thomson, A.M. and Perry, J. L. (2006). Collaboration Processes: Inside the Black Box. Public Administration Review, 66, 20-32.

Thorelli, H. B. (1986). Networks: Between markets and hierarchies. Strategic Management Journal, 7(1), 37-51.

Tortoriello, M., Reagans, R., McEvily, B. (2012). Bridging the Knowledge Gap: The Influence of Strong Ties, Network Cohesion, and Network Range on the Transfer of Knowledge Between Organizational Units. Organization Science, 23(4), 1024-1039.

Tsai, W. (2001). Knowledge transfer in intraorganizational networks: Effects of network position and absorptive capacity on business unit innovation and performance. Academy of Management Journal, 44(5), 996-1004.

Um, K-H. and Kim, S-M. (2019). The effects of supply chain collaboration on performance and transaction cost advantage: The moderation and nonlinear effects of governance mechanisms. International Journal of Production Economics, 217, 97-111.

Uzzi, B. (1996). The Sources and Consequences of Embeddedness for the Economic Performance of Organizations: The Network Effect. American Sociological Review, 61, 674-698.

Uzzi, B. (1997). Social Structure and Competition in Interfirm Networks: The Paradox of Embeddedness. Administrative Science Quarterly, 42(1), 35-67.

Vereecke, A., Van Dierdonck, R., De Meyer, A. (2006). A typology of plants in global manufacturing networks. Management Science, 52(11), 1737-1750.

Vurro, C., Russo, A., Perrini, F. (2009). Shaping Sustainable Value Chains: Network Determinants of Supply Chain Governance Models. Journal of Business Ethics, 90, 607-621.

Walker, J.T., Fenton, E., Salter, A. and Salandra, R. (2019). What Influences Business Academics' Use of the Association of Business Schools (ABS List)? Evidence From a Survey of UK Academics. British Journal of Management, 30(3), 730-747.

Wasserman, S. and Faust, K. (1994). Social Network Analysis: Methods and Applications. Cambridge University Press, Cambridge.

Westney, D. E. (1993). Cross-Pacific internationalization of R\&D by U.S. and Japanese firms. R\&D Management, 23(2), 171-181. 
Wetzstein, A., Feisel, E., Hartmann, E., Benton, W. C. (2019). Uncovering the Supplier Selection Knowledge Structure: A systematic citation network analysis from 1991 to 2017. Journal of Purchasing and Supply Management, 25(4), 100519.

Whang, S. (1995). Coordination in operations: A taxonomy. Journal of Operations Management, 12, 413-422.

Williamson, O.E. (1985). The Economic Institutions of Capitalism. New York: The Free Press.

Williamson, O.E. (1993). Transaction Cost Economics and Organization Theory. Industrial and Corporate Change, 2(2), 107-156.

Williamson, O.E. (1996). The Mechanisms of Governance. Oxford: Oxford University Press.

Wu, L-Y., Wang, C-J., Tseng, C-Y., Wu, M-C. (2009). Founding team and start-up competitive advantage. Management Decision, 47(2), 345-358.

Yim, F.H-K., Forman, H., Kwa, H. (2013). Factors affecting new product post-adoption behavior in a major US automotive supply chain: an examination of antecedents to technology internalization. Journal of Business \& Industrial Marketing, 28/2, 147159.

Zaheer, A. and Bell, G. G. (2005). Benefiting from network position: firm capabilities, structural holes, and performance. Strategic Management Journal, 26(9), 809-825.

Zaheer, A. and Zaheer, S. (1997). Catching the wave: Alertness, responsiveness, and market influence in global electronic networks. Management Science, 43(11), 1493-1509.

Zaheer, A., Gözübüyük, R., Milanov, H. (2010). It's the Connections: The Network Perspective in Interorganizational Research. Academy of Management Perspectives, 24(1), $62-77$.

Zaidat, A., Boucher, X., Vincent, L. (2005). A framework for organization network engineering and integration. Robotics and Computer-Integrated Manufacturing, 21, 259271.

Žigić, k. and Maçi, I. (2011). Competition policy and market leaders. Economic Modelling, 28(3), 1042-1049. 